
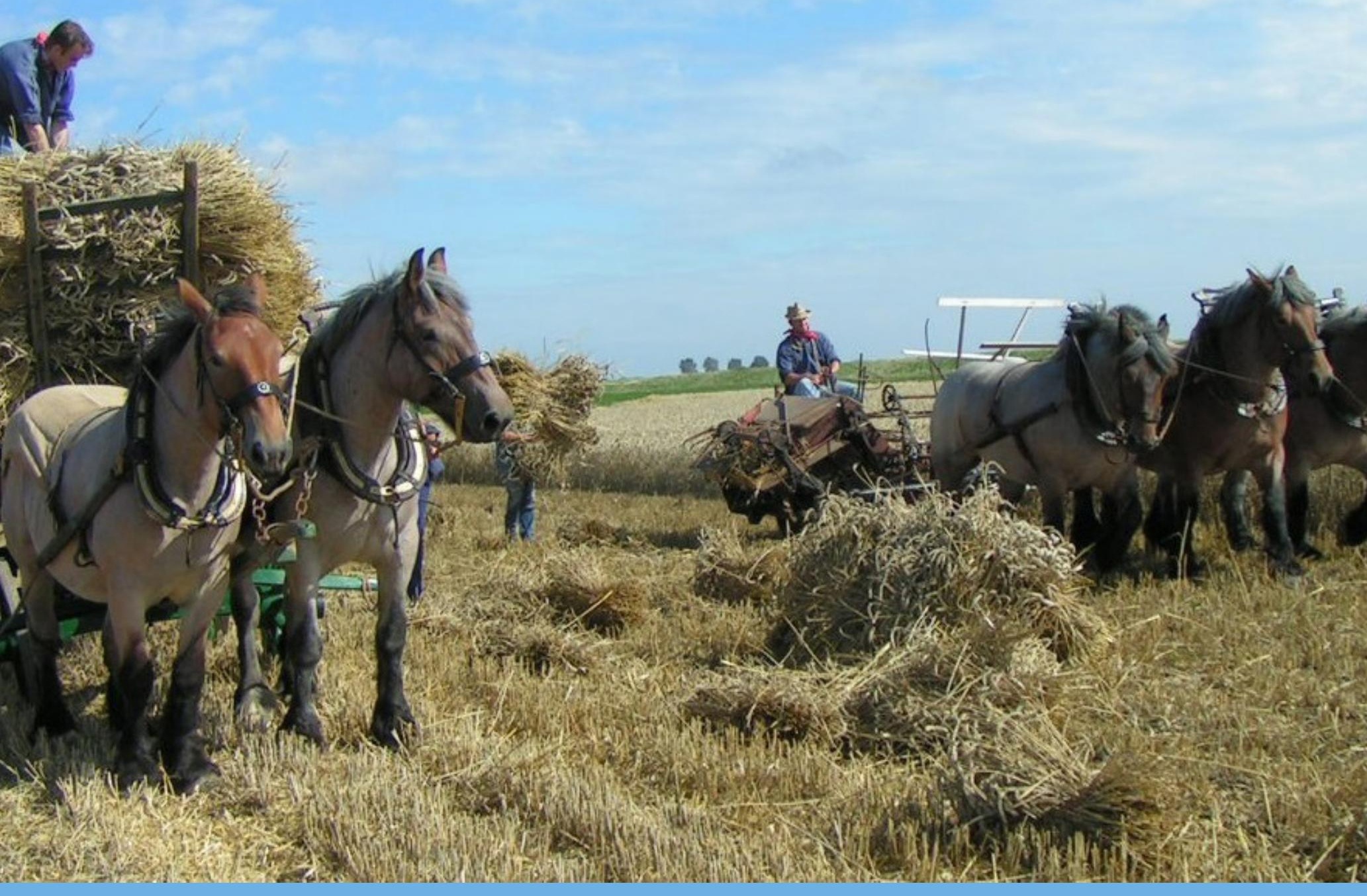

\title{
Noodzaak voor genetisch beheer van de Nederlandse trekpaardenpopulatie
}

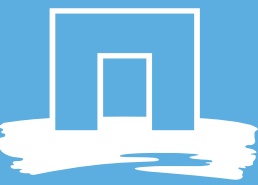

\section{WAGENINGEN}

UNIVERSITY \& RESEARᄃH 



\section{Noodzaak voor genetisch beheer van de Nederlandse Trekpaardenpopulatie}

Anouk Schurink $^{1,2}$, Sipke Joost Hiemstra ${ }^{1}$, Kor Oldenbroek ${ }^{1}$, Agnes de Wit ${ }^{1,2}$, Bart Ducro ${ }^{2}$, Jack Windig ${ }^{1,2}$

1 Centre for Genetic Resources, the Netherlands (CGN)

2 Animal Breeding and Genomics, Wageningen University \& Research

Dit onderzoek is uitgevoerd door CGN, in opdracht van en gefinancierd door het ministerie van Landbouw, Natuur en Voedselkwaliteit (LNV), in het kader van WOT-03 Genetische Bronnen (projectnummer WOT-03-003-056) 
Schurink, A., S.J. Hiemstra, J.K. Oldenbroek, A. de Wit, B.J. Ducro, J.J. Windig, 2018. Noodzaak voor genetisch beheer van de Nederlandse Trekpaardenpopulatie; Centre for Genetic Resources, the Netherlands (CGN), Wageningen University \& Research, CGN rapport 41 . 38 blz.; 12 fig.; 8 tab.; 7 ref.

Samenvatting - Het Nederlandse Trekpaard is een zeldzaam Nederlands paardenras. Voor de instandhouding van zeldzame rassen is het van groot belang om de populatiegrootte en de toename in inteelt en verwantschap in de populatie te monitoren. Uit het doorlichten van de Nederlandse Trekpaardenpopulatie bleek dat inteelt (en eventuele bijbehorende gevolgen) beter moeten worden beheerst door het stamboek (KVTH) én met medewerking van fokkers. In de meest recente generatie (2010-2017) werden minder veulens geboren dan in de generatie ervoor, er werden verhoudingsgewijs ook minder Trekpaarden ingezet voor de fokkerij terwijl de verwantschap tussen de paarden aanzienlijk toenam. De berekende inteelttoename bevindt zich ruim boven de door de FAO gestelde norm van maximaal $0,5 \%$ per generatie. Door aangepast genetisch beheer is het mogelijk de inteelttoename drastisch terug te dringen.

Op basis van de analyse en de simulaties is een aantal adviezen is geformuleerd die kunnen bijdragen aan het terugdringen van de inteelttoename:

- De verwantschap van de dekhengsten en hengsten uit de genenbank met de huidige populatie publiceren. Dit zou aan de hand van stoplichtkleuren kunnen gebeuren om de waarde van een hengst met oog op genetische diversiteit te visualiseren. Daarnaast zal publicatie van verwantschap naar verwachting bijdragen aan de bewustwording bij fokkers;

- Het stimuleren van gebruik van dekhengsten en hengsten uit de genenbank met een lage verwantschap om meer genetische diversiteit in de populatie te brengen. Én, het gebruik van hengsten met een hoge verwantschap tot de populatie afraden;

- Het meer gelijkmatig inzetten van dekhengsten, zodat niet een beperkt aantal dekhengsten een groot deel van de fokmerries dekt;

- Inteeltberekeningen uitvoeren voor de individuele merriehouder: bij de paringskeuze wordt het inteeltpercentage van fictieve nakomelingen berekend, waarbij de merrie fictief wordt gepaard met elke beschikbare dekhengst. Een dekhengst met lagere verwantschap tot de merrie resulteert in een nakomeling met een lagere inteeltpercentage;

- $\quad$ Bij de beslissing om een hengst te selecteren de gemiddelde verwantschap tot de populatie meenemen in de afweging, dat is positief discrimineren;

- $\quad$ Het uitbreiden van de genenbank collectie voor het Nederlands Trekpaard, bij voorkeur met hengsten met een lage verwantschap met de populatie, om genetische diversiteit veilig te stellen;

- $\quad$ Het geven van voorlichting over inteelt en de mogelijke gevolgen ervan om bewustwording te vergroten;

- $\quad$ Meer uitwisseling van paarden met de Belgische Trekpaardenpopulatie zou kunnen bijdragen aan het terugdringen van de inteelttoename. Om de waarde hiervan te kunnen vaststellen, is vervolgonderzoek nodig waarin beide populaties worden meegenomen;

- Het vergroten van de fokpopulatie door meer mensen te interesseren voor de fokkerij en daarmee het aantal geboren veulens (die op latere leeftijd worden ingezet in de fokkerij) per jaar te verhogen.

Summary - The Dutch Draught horse is a rare Dutch horse breed. To conserve rare breeds, it is of great importance to monitor population size and increase in inbreeding and kinship in a population. When screening the Dutch Draught horse population, it turned out that inbreeding (and potential consequences) should be controlled by the studbook (KVTH) with participation of breeders. During the most recent generation (2010-2017) fewer foals were born annually compared to the generation before. Also, the percentage of foals that is used in breeding at a later age decreased steadily. At the same time there is a considerable increase in the kinship between horses that are used in breeding. The increase in inbreeding passes the FAO threshold of $0.5 \%$ per generation. In light of the increase in kinship, we expect that the increase in inbreeding will even be higher in the future. Screening the population clearly showed that genetic management is needed to be able to better control inbreeding (and potential accompanying consequences). It is possible to drastically reduce the inbreeding increase through genetic management. 
Based on the analysis and simulations several advices were formulated that could contribute to a better control of inbreeding:

- Publish the average kinship of stallions (in situ and from the gene bank collection) with the current population, based on traffic light colours;

- Stimulate the use of stallions (in situ and from the gene bank collection) with limited kinship and more evenly use of stallions in the population. And discourage the use of stallions with a high kinship to the population;

- More balanced use of stallions, preventing that a few stallions cover a large part of the mares;

- Inbreeding calculation for the individual mare owner: when choosing a stallion to mate to their mare, calculate the inbreeding percentage of a fictional offspring;

- Consider the average kinship when selecting stallions at inspections, that is positive discrimination;

- Increase the gene bank collection for the Dutch Draught horse, preferably with stallions with limited kinship to the population;

- Inform about inbreeding and its potential consequences to increase awareness;

- More exchange from horses from the Belgian Draught horse population could contribute to a better control of inbreeding. Its value should still be established, so more research is needed in which both populations are considered;

- Increase the size of the breeding population by interesting more people to breeding and with that increase the number of foals born annually (and used in breeding at a later age).

Dit rapport is gratis te downloaden op http://doi.org/10.18174/465037 of op

www.wur.nl/cgn onder CGN rapporten.

(C) 2018 Centre for Genetic Resources, the Netherlands (CGN), Wageningen University \& Research E cgn@wur.nl

Wageningen University \& Research aanvaardt geen aansprakelijkheid voor eventuele schade voortvloeiend uit het gebruik van de resultaten van dit onderzoek of de toepassing van de adviezen.

Alle rechten voorbehouden. Niets uit deze uitgave mag worden vermenigvuldigd en/of openbaar gemaakt worden door middel van druk, fotokopie, microfilm of op welke wijze dan ook zonder voorafgaande toestemming van de uitgever of auteur.

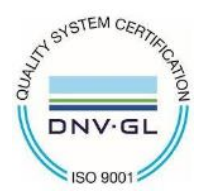

De certificering volgens ISO 9001 onderstreept ons kwaliteitsniveau. 


\section{Inhoud}

$\begin{array}{ll}\text { Woord vooraf } & 7\end{array}$

$\begin{array}{ll}\text { Samenvatting } & 9\end{array}$

$1 \quad$ Introductie

11

1.1 Het Nederlandse Trekpaard 11

$\begin{array}{ll}1.1 .1 \text { Geschiedenis } & 11\end{array}$

$\begin{array}{ll}1.1 .2 \text { Gebruik } & 12\end{array}$

$\begin{array}{ll}1.1 .3 \text { Rasbeschrijving } & 12\end{array}$

$\begin{array}{lll}1.2 & \text { Inteelt en verwantschap } & 13\end{array}$

$\begin{array}{lll}1.3 & \text { Genenbank collectie (status 2017) } & 13\end{array}$

1.4 Doelstellingen $\quad 13$

2

Materiaal en methodes $\quad 14$

$\begin{array}{lll}2.1 & \text { Beschikbaar gestelde gegevens } & 14\end{array}$

2.2 Kwaliteitscontrole en data editing 14

$\begin{array}{lll}2.3 & \text { Uitgevoerde analyses } & 14\end{array}$

3

$\begin{array}{ll}\text { Doorlichten populatie } & 15\end{array}$

$\begin{array}{lll}3.1 & \text { Beschrijving beschikbaar gestelde gegevens } & 15\end{array}$

$\begin{array}{ll}3.1 .1 \text { Geslacht } & 15\end{array}$

$\begin{array}{ll}3.1 .2 \text { Stamboom } & 15\end{array}$

3.1.3 Stamboom compleetheid $\quad 15$

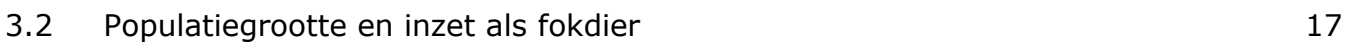

$\begin{array}{lll}3.3 & \text { Generatie interval } & 19\end{array}$

3.4 Inteeltpercentage, verwantschap en -toename $\quad 19$

$4 \quad$ Advies genetisch beheer $\quad 21$

$\begin{array}{lll}4.1 & \text { Simulaties } & 21\end{array}$

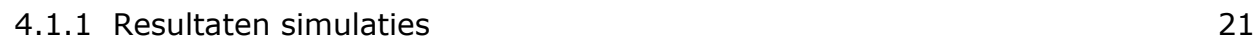

$\begin{array}{lll}4.2 & \text { Advies } & 22\end{array}$

$5 \quad$ Advies aanvulling genenbank $\quad 23$

5.1 Kandidaat dekhengsten voor aanvulling genenbank 23

5.2 Verwantschap tussen (fok)populatie en kandidaat dekhengsten voor aanvulling genenbank $\quad 23$

5.2.1 Verwantschap tussen groepen binnen het Nederlands Trekpaard 23

5.2.2 Verwantschap tussen individuele hengsten en de huidige (fok)populatie 24

$\begin{array}{lll}5.3 & \text { Geselecteerde dekhengsten voor aanvulling genenbank } & 25\end{array}$

$6 \quad$ Conclusies en aanbevelingen $\quad 27$

6.1 Aanleiding, doelstelling en analyses $\quad 27$

6.2 Het doorlichten van de Nederlandse Trekpaardenpopulatie $\quad 27$

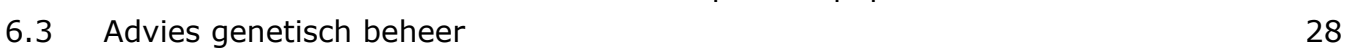

6.4 Advies aanvulling genenbank collectie Nederlands Trekpaard 29

$\begin{array}{ll}\text { Literatuur } & \mathbf{3 0}\end{array}$

Bijlage 1 Genenbank collectie Nederlands Trekpaard (status 2017) 31 
Bijlage 2 Verwantschap tussen de huidige (fok)populatie en kandidaat dekhengsten voor aanvulling van de genenbank collectie

Bijlage 3 Verwantschap tussen de huidige (fok)populatie en hengsten waarvan reeds sperma is opgeslagen in de genenbank

Bijlage 4 Verwantschap tussen hengsten waarvan eind 2017 reeds sperma is veiliggesteld in de genenbank 


\section{Woord vooraf}

Het Centrum voor Genetische Bronnen Nederland (CGN) geeft op aanvraag technische ondersteuning aan rasverenigingen en stamboeken over het behoud van genetische diversiteit en duurzame ontwikkeling van landbouwhuisdierrassen. Daarbij ligt de nadruk op de ontwikkeling en evaluatie van fokstrategieën, waarbij enerzijds de genetische diversiteit van het ras behouden wordt en anderzijds het ras ook beter benut kan worden. Het veiligstellen van materiaal in de genenbank draagt tevens bij aan het conserveren van deze rassen. Het CGN bepaalt in overleg met rasorganisaties welke dieren in de genenbank opgeslagen moeten worden en welke dieren uit de genenbank opnieuw ingezet worden om de genetische diversiteit van de levende populatie te verbreden. Deze keuzes worden gemaakt op basis van afstammingsgegevens, maar zo mogelijk worden ook DNA analyses hiervoor gebruikt. 


\section{Samenvatting}

Het Nederlandse Trekpaard is een zeldzaam Nederlands paardenras. Voor de instandhouding van zeldzame rassen is het van groot belang om de populatiegrootte en de toename in inteelt en verwantschap in de populatie te monitoren. Daarom is de Nederlandse Trekpaardenpopulatie doorgelicht op basis van afstammingsgegevens om te onderzoeken hoe de huidige populatie er voor staat qua grootte, inteelt en verwantschap, is er een advies geformuleerd met betrekking tot het genetisch beheer van deze populatie en zijn genetisch interessante Trekpaardhengsten geïdentificeerd voor aanvulling van de genenbank collectie. Het doorlichten van de populatie van in totaal 25.671 Trekpaarden (dood en levend) liet zien dat er een duidelijke afname is in het aantal veulens dat jaarlijks geboren wordt. Waar in de periode van 1996-2009 nog gemiddeld 655 veulens per jaar werden geboren, daalde het aantal veulens per geboortejaar in de periode van 2010-2016 gestaag naar 320 in 2016. Daarnaast daalt het percentage veulens dat op latere leeftijd wordt ingezet in de fokkerij ook gestaag. Twee generaties geleden werd nog circa $50 \%$ van de merrieveulens en $10 \%$ van de hengstveulens op latere leeftijd ingezet in de fokkerij. In de huidige generatie zijn deze percentages gereduceerd tot circa $20 \%$ voor de merrieveulens en $3 \%$ voor de hengstveulens. Tegelijkertijd is er een aanzienlijke stijging in de verwantschap tussen de paarden die worden ingezet voor de fokkerij. De gemiddelde verwantschap steeg met 0,5\% in de periode van 1987-1997, met $0,7 \%$ in 1997-2007 en met ruim 1,3\% in de periode $2007-2017$. Met de berekende inteelttoename reeds boven de door FAO gestelde norm van 0,5\% per generatie (inteelttoename bedroeg 1,3\% in de periode van 2007-2017), is de voorspelling dat de inteelttoename in de toekomst nog verder zal stijgen. Het doorlichten van de populatie liet duidelijk de noodzaak zien voor genetisch beheer van de populatie om inteelt (en eventuele bijbehorende gevolgen) beter te beheersen. Door aangepast genetisch beheer is het mogelijk de inteelttoename drastisch terug te dringen. Alle gesimuleerde maatregelen hebben een positief effect op het terug dringen van inteelttoenamen, maar sturen op verwantschap is het meest effectief.

Concreet geformuleerde adviezen op basis van de analyse en de simulaties, die kunnen bijdragen aan het terugdringen van de inteelttoename, zijn:

- De verwantschap van de dekhengsten en hengsten uit de genenbank met de huidige populatie publiceren. Dit zou aan de hand van stoplichtkleuren kunnen gebeuren om de waarde van een hengst met oog op genetische diversiteit te visualiseren. Daarnaast zal publicatie van verwantschap naar verwachting bijdragen aan de bewustwording bij fokkers;

- Het stimuleren van gebruik van dekhengsten en hengsten uit de genenbank met een lage verwantschap om meer genetische diversiteit in de populatie te brengen. Én, het gebruik van hengsten met een hoge verwantschap tot de populatie afraden;

- Het meer gelijkmatig inzetten van dekhengsten, zodat niet een beperkt aantal dekhengsten een groot deel van de fokmerries dekt;

- Inteeltberekeningen uitvoeren voor de individuele merriehouder: bij de paringskeuze wordt het inteeltpercentage van fictieve nakomelingen berekend, waarbij de merrie fictief wordt gepaard met elke beschikbare dekhengst. Een dekhengst met lagere verwantschap tot de merrie resulteert in een nakomeling met een lagere inteeltpercentage;

- $\quad$ Bij de beslissing om een hengst te selecteren de gemiddelde verwantschap tot de populatie meenemen in de afweging, dat is positief discrimineren;

- Het uitbreiden van de genenbank collectie voor het Nederlands Trekpaard, bij voorkeur met hengsten met een lage verwantschap met de populatie, om genetische diversiteit veilig te stellen;

- Het geven van voorlichting over inteelt en de mogelijke gevolgen ervan om bewustwording te vergroten;

- Meer uitwisseling van paarden met de Belgische Trekpaardenpopulatie zou kunnen bijdragen aan het terugdringen van de inteelttoename. Om de waarde hiervan te kunnen vaststellen, is vervolgonderzoek nodig waarin beide populaties worden meegenomen; 
- Het vergroten van de fokpopulatie door meer mensen te interesseren voor de fokkerij en daarmee het aantal geboren veulens (die op latere leeftijd worden ingezet in de fokkerij) per jaar te verhogen. 


\section{$1 \quad$ Introductie}

Het CGN ondersteunt en adviseert stamboeken en rasorganisaties, zoals het KVTH, om landbouwhuisdierrassen op een gezonde manier in stand te houden. Prachtige oude rassen in Nederland, zoals het Trekpaard, die het waard zijn om te behouden voor de toekomst omdat ze deel uit maken van ons Nederlandse culturele erfgoed. Vaak zijn dit ook zeldzame rassen omdat er nog maar een beperkt aantal dieren van zijn, wat risico's met zich meebrengt op het gebied van inteelt en uiteindelijk uitsterven van een ras. Door een te sterke inteelttoename is het aannemelijk dat de negatieve gevolgen van inteelt zichtbaar worden in een populatie; de kans op het ontstaan van erfelijke gebreken is verhoogd, inteeltdepressie kan optreden waardoor de algehele vitaliteit en vruchtbaarheid van paarden verminderd, en op langere termijn bepaalde kenmerken verloren kunnen gaan. Om de stamboeken en rasorganisaties zo goed mogelijk te ondersteunen en adviseren, worden ontwikkelingen op het gebied van fokkerij in een ras van tijd tot tijd gemonitord en materiaal van interessante dieren veiliggesteld in de genenbank. Aangezien het al een tijdje geleden is geweest dat de Nederlandse Trekpaardenpopulatie is doorgelicht, heeft het CGN in 2018 uitgebreid populatie genetisch onderzoek uitgevoerd om vast te stellen hoe de huidige populatie er genetisch gezien voor staat.

Hoofdstuk 1 geeft een beschrijving van het Nederlandse Trekpaard. Daarnaast wordt kort ingegaan op onderzoek naar inteelt en verwantschap wat voorheen reeds is uitgevoerd voor het Nederlandse Trekpaard en stilgestaan bij de huidige genenbank collectie voor dit paardenras. Daaruit voortvloeiend worden de doelstellingen van het huidige onderzoek beschreven.

\section{$1.1 \quad$ Het Nederlandse Trekpaard}

De in deze sectie gegeven geschiedenis, gebruik en rasbeschrijving van het Nederlandse Trekpaard is voor dit rapport geheel belangeloos geschreven door Jos Peerlings, één van de auteurs van het boek "Het trekpaard" (Peerlings et al., 2007). Een nog meer uitgebreide omschrijving van het Nederlands Trekpaard en zijn ontstaan is te vinden in dit boek en in het CGN rapport 17 (de Weerd en Oldenbroek, 2010).

\subsubsection{Geschiedenis}

Eind 19e eeuw nam de industrialisatie en de daarmee gepaard gaande trek naar steden en professionalisering van de landbouw een grote vlucht. Daarmee ontstond een grote vraag naar trekkracht. Uit de destijds aanwezige koudbloed paarden werd in België de basis gelegd voor wat nu het Belgische Trekpaard is. Een gespecialiseerd Trekpaard dat al snel heel populair en veelgevraagd werd. Veel Belgische Trekpaarden vonden eind 19e en begin 20e eeuw hun weg richting eerst de provincie Zeeland en later geheel Nederland. Vandaar de benamingen Zeeuws Trekpaard en "Belg". Tegenwoordig vormen het Belgische en Nederlandse Trekpaard één ras waarbinnen onderling volop fokdieren worden uitgewisseld.

In de jaren voor, in en direct na de Tweede Wereldoorlog was het Nederlandse Trekpaard het belangrijkste paardenras in Nederland. Met het verder opkomen van de mechanisatie, vanaf de jaren zestig vorige eeuw, is het aantal Trekpaarden fors afgenomen. Het gebruik als werkpaard in landbouw, bosbouw en industrie is nagenoeg historie. Wat tegelijkertijd het Nederlandse Trekpaard een belangrijk cultureel erfgoed maakt. In de huidige tijd worden Trekpaarden gebruikt voor keuringen en tentoonstellingen, als rijdier en aangespannen voor recreatieve doeleinden. Het imposante voorkomen en vriendelijke karakter maken van het Trekpaard een publiekstrekker. 


\subsubsection{Gebruik}

Het Trekpaard is van oorsprong gefokt voor het stappend trekken van zware lasten en verrichten van werkzaamheden op het land. Met de komst van de mechanisatie werden de Trekpaarden lichter en werd een ruime stap en vlotte draf gevraagd voor gebruik bij zware transporten over de weg. Anno nu gebruiken nog slechts enkele boeren hun Trekpaard voor het verrichten van werkzaamheden op het land. Recreatief zijn er nog wel onderlinge ploegwedstrijden. Helaas laten steeds minder natuurorganisaties omgezaagde bomen uit de bossen slepen via paardenkracht. Er zijn nog enkele bomenslepers, met name ook in België en Duitsland, die werken met Trekpaarden. In enkele gevallen worden ze ingezet voor de paardenmelkerij.

Een deel van de eigenaren van stamboekpaarden neemt deel aan keuringen en tentoonstellingen. Naast de verplichte stamboekkeuringen wordt ook de onderlinge competitie aangegaan met als inzet de kopposities. Met shows en presentaties worden zoveel mogelijk bezoekers getrokken.

Heel populair zijn de ringsteekwedstrijden, die met name in Zeeland worden gehouden. Daarvoor worden overwegend Trekpaarden gebruikt. Een andere folkloristische activiteit in Zeeland is het Strao rijden waarbij in februari paarden en ruiters versierd de zee ingaan.

In toenemende mate worden Trekpaarden gebruikt als rijpaard, mede vanwege hun prettige en rustige karakter. Ook het aangespannen rijden kent een groeiende populariteit. Vaak zijn er op evenementen demonstraties met Trekpaarden. In alle gevallen kunnen Trekpaarden, door hun indrukwekkende omvang en rustige karakter rekenen op veel publieke belangstelling.

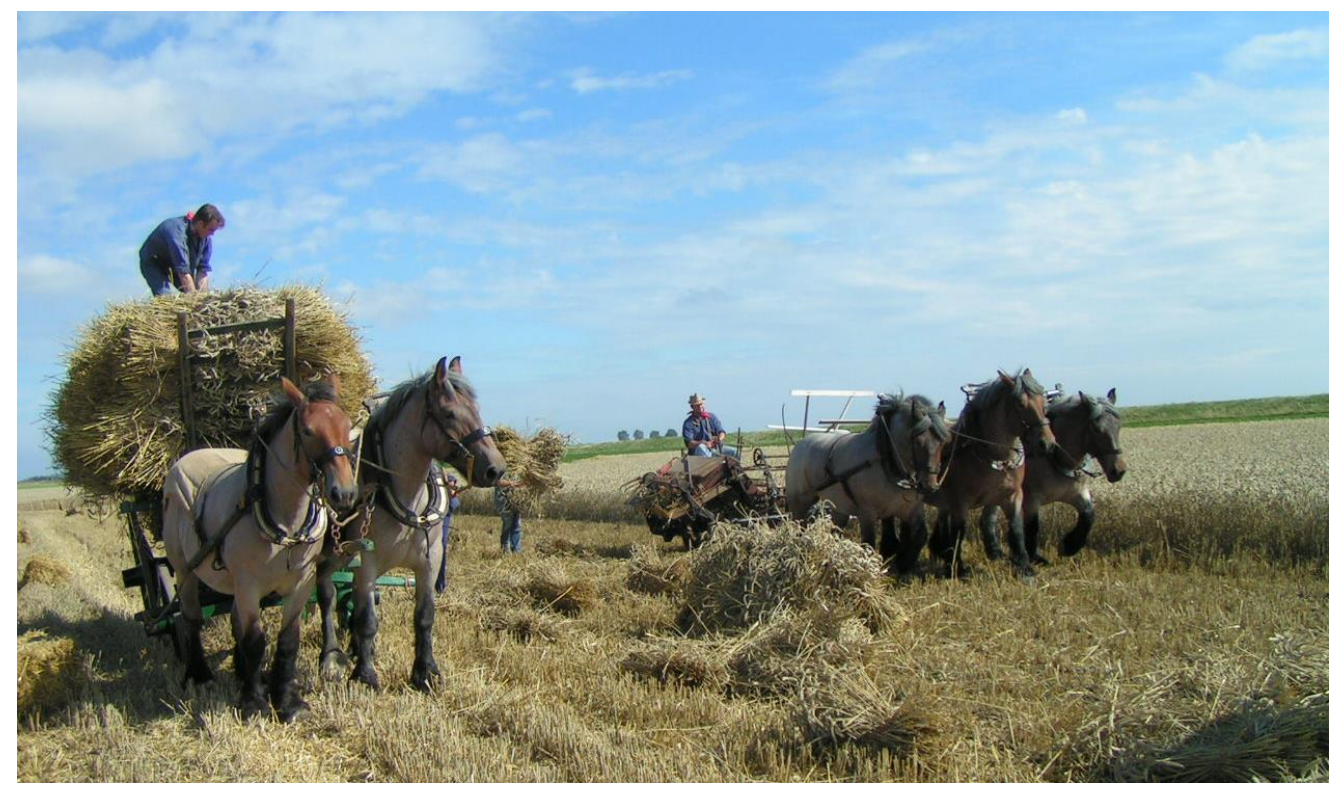

Figuur 1.1 Nederlandse Trekpaarden aan het werk op 't land. Foto: Myrthe Maurice-van Eijndhoven.

\subsubsection{Rasbeschrijving}

Het Nederlandse Trekpaard is een zwaar koudbloedras met een rustig vriendelijk karakter en grote bereidheid om te werken. Als zodanig was en is het gewaardeerd als werkpaard maar ook voor gebruik in recreatie.

Het hoofd is verhoudingsgewijs klein, mooi gevormd. De ogen zijn groot, de oren kort en spits. De hals is kort en goed gespierd. De schoft is de plek waar de schouderbladen samen komen en waar ook de schofthoogte wordt gemeten. De schoft is lang en breed, en met een brede borstkas. De schouders zijn lang en liggen schuin naar achteren. De rug is kort, recht, breed en goed gespierd. De rug gaat in één lijn over via de gespierde lendenen in het kruis. 
Het kruis is lang en breed en iets hellend. Van achteren gezien is het kruis gespierd en gespleten. De broek is fors gespierd met van achteren gezien brede, bolvormige broekspieren. De schenkel is rondom breed, zwaar gespierd en voldoende lang. De staart was veelal gecoupeerd maar routinematig couperen is tegenwoordig niet meer toegestaan. De voorborst moet voldoende breed zijn en gespierd. De lange gewelfde ribben zorgen voor voldoende inhoud van de borstkas en daarmee ruimte voor hart en longen. De buik is rond met veel volume. De schofthoogte bij Trekpaarden varieert bij hengsten tussen 1,60 en 1,75 meter. Bij volwassen merries varieert de schofthoogte tussen 1,55 en 1,70 meter.

\subsection{Inteelt en verwantschap}

In 2009 is reeds eerder een onderzoek uitgevoerd naar inteelt en verwantschap in de Nederlandse en Belgische Trekpaardenpopulaties (García et al., 2009). De belangrijkste bevindingen van de analyse van de stambomen van deze Trekpaarden waren dat het gemiddelde inteeltpercentage van de meest recente generatie $5 \%$ was (op basis van 5 generaties) en de inteelttoename van de meest recente generatie $0,5 \%$ bedroeg en daarmee net lag op de richtlijn van de FAO (FAO, 2013). De auteurs concludeerden dat behoud van genetische diversiteit aandacht verdient binnen het fokprogramma van de KVTH maar dat er nog geen sprake was van een kritieke situatie. Het advies was om binnen het fokprogramma de genetische contributie van een klein aantal hengsten in te perken.

Onderdeel van het levend bewaren van zeldzame rassen in situ is het van tijd tot tijd monitoren van ontwikkelingen binnen een ras. In afstemming met het KVTH, in het licht van de door García et al. (2009) berekende inteelttoename en de verstreken jaren, is de Nederlandse Trekpaardenpopulatie in 2018 wederom doorgelicht.

\subsection{Genenbank collectie (status 2017)}

Eind 2017 was sperma van 28 verschillende dekhengsten opgeslagen in de genenbank (Bijlage 1). Het aantal doses sperma per hengst en de kwaliteit van het sperma varieert wel veel (Bijlage 1; een inseminatiedoses bevat een bepaalde gestandaardiseerde hoeveelheid levende zaadcellen waarmee in theorie een bevruchting mogelijk zou moeten zijn; door verschil in spermakwaliteit tussen hengsten zal van een hengst met slechte spermakwaliteit meer sperma opgeslagen moeten worden dan van een hengst met goede spermakwaliteit).

Voor elk zeldzaam Nederlands ras heeft de genenbank zich ten doel gesteld om een zogeheten core collectie op te bouwen. Dit houdt in dat, voor elk zeldzaam Nederlands paardenras, van 50 zo min mogelijk gerelateerde hengsten minimaal 50 inseminatiedoses worden veiliggesteld in de genenbank. Met deze core collectie zou een ras weer gereconstrueerd kunnen worden wanneer het in situ is verdwenen. Op basis van de huidige genenbank collectie Trekpaard kan geconcludeerd worden dat voor dit ras nog geen core collectie is behaald.

\subsection{Doelstellingen}

Het in dit rapport beschreven onderzoek omvat een drietal doelstellingen:

1. Het doorlichten van de Nederlandse Trekpaardenpopulatie op basis van afstammingsgegevens om te onderzoeken hoe de huidige populatie er voor staat [qua aantallen, (toename in) inteelt en verwantschap tussen paarden];

2. Op basis van de resultaten onder 1 . en simulaties van mogelijke aanpassingen in het fokprogramma, een advies geven over het genetisch beheer van de Nederlandse Trekpaardenpopulatie;

3. Het identificeren van genetisch interessante Trekpaardhengsten op basis van afstammingsgegevens voor aanvulling van de genenbank collectie. 


\section{$2 \quad$ Materiaal en methodes}

De beschikbaar gestelde afstammingsgegevens van alle Trekpaarden geregistreerd door de Koninklijke Vereniging "Het Nederlandse Trekpaard en De Haflinger" werden geanalyseerd en diverse scenario's met betrekking tot genetische beheer gesimuleerd om de in paragraaf 1.4 beschreven doelstellingen te realiseren.

\subsection{Beschikbaar gestelde gegevens}

De beschikbaar gestelde gegevens bevatte alle door het KVTH in het digitale systeem geregistreerde Trekpaarden. Beschikbare informatie per paard was: vader, moeder, geslacht, naam en geboortedatum. Deze gegevens werden aangeleverd voor in totaal 25.998 Trekpaarden.

\subsection{Kwaliteitscontrole en data editing}

Gegevens van 25.998 Trekpaarden werden aangeleverd vanuit de digitale database. Deze paarden vertegenwoordigen hoogstwaarschijnlijk de (complete) recente generaties met daarbij al hun voorouders (zie ook 3.2 Populatiegrootte en inzet als fokdier). Uiteindelijk werden gegevens van 327 Trekpaarden verwijderd omdat hun stamboom compleet onbekend was en ze geen nakomeling(en) voort hebben gebracht. Gedurende de analyses werden dus gegevens van 25.671 Trekpaarden gebruikt.

Een aantal paarden werd als zowel vader als moeder aangemerkt in de stambomen. Het correcte geslacht werd in afstemming met het KVTH vastgesteld. Onterecht toegewezen ouderschap werd gecorrigeerd door voor het betreffende paard de ouder op onbekend te zetten.

Daarnaast diende het geboortejaar van een aantal paarden gecorrigeerd te worden aangezien het geboortejaar van nakomeling(en) voor die van hun ouder(s) was. Wederom werd dit uitgevoerd in afstemming met het KVTH.

Geboortejaar van ruim 6.500 paarden was niet geregistreerd. Om trends zo goed mogelijk te kunnen weergeven (bijv. inteeltpercentage per geboortejaar en daarmee inteelttoename), is voor zo veel mogelijk paarden geprobeerd een zo goed mogelijke schatting te maken van het geboortejaar. Daarbij is het onbekende geboortejaar van een paard geschat als het gemiddelde geboortejaar van de nakomeling(en) minus het generatie interval (wat 7 jaar bedroeg). Met behulp van deze berekening kon het geboortejaar van circa 3.000 paarden worden geschat en meegenomen in de analyses.

\subsection{Uitgevoerde analyses}

Resultaten met betrekking tot onder andere populatiegrootte, inteeltpercentages en toename in inteelt en verwantschap werden verkregen middels het programma Inteeltmonitor. Daarnaast werd het programma CFC (Sargolzaei et al., 2006) gebruikt om de individuele verwantschap te berekenen tussen (dek)hengsten en ook tussen diverse groepen (dek)hengsten: reeds aanwezig in de genenbank collectie, voormalige (dek)hengsten en huidige actieve (dek)hengsten. Identificatie van genetisch interessante hengsten voor aanvulling van de genenbank collectie gebeurde met het programma GenCont, waarmee de combinatie van paarden met de laagste verwantschap en hoogste genetische diversiteit wordt berekend. Diverse scenario's voor mogelijk benodigde aanpassingen in het fokprogramma werden gesimuleerd met behulp van het programma GenManSim (Windig \& Oldenbroek). Met dit programma wordt de populatie in de computer nagebootst voor meerdere generaties en het verloop van de inteelt bepaald, waarbij verschillende vormen van genetisch beheer gesimuleerd en vergeleken kunnen worden. 


\section{Doorlichten populatie}

De beschikbaar gestelde afstammingsgegevens van de bij het KVTH in de digitale database geregistreerde Trekpaarden (25.671 na kwaliteitscontrole en data editing) werden doorgelicht om onder andere te onderzoeken hoe de huidige populatie er voor staat qua omvang, (toename in) inteelt en verwantschap tussen paarden.

\subsection{Beschrijving beschikbaar gestelde gegevens}

\subsubsection{Geslacht}

Net iets meer dan 70\% van de bij de KVTH geregistreerde Trekpaarden was merrie, bijna 30\% was hengst (Tabel 3.1). Aangezien er bij de geboorte een even grote kans bestaat op een merrie als een hengst, kan er vastgesteld worden dat er bij de KVTH minder hengsten worden geregistreerd.

Castratie van hengsten werd beperkt doorgegeven aan de KVTH, aangezien slechts 174 ruinen staan geregistreerd.

Tabel 3.1 Geslacht van de 25.671 bij de KVTH geregistreerde Trekpaarden.

\begin{tabular}{lrr} 
Geslacht & Aantal & Percentage \\
Merrie & 18.162 & $70,7 \%$ \\
\hline Hengst & 7.335 & $28,6 \%$ \\
\hline Ruin & 174 & $0,7 \%$ \\
\hline
\end{tabular}

\subsubsection{Stamboom}

De 25.671 bij de KVTH geregistreerde Trekpaarden stamden af van 1.995 vaders en 11.009 moeders. Het merendeel van de vaders $(39,7 \%)$ en moeders $(58,5 \%)$ bracht slechts één nakomeling voort (Figuur 3.1). Een vergelijkbare verdeling qua aantal nakomelingen per moeder wordt ook gevonden in andere paardenrassen. Het percentage vaders met een beperkt aantal nakomelingen $(\leq 5)$ is aanzienlijk hoog.
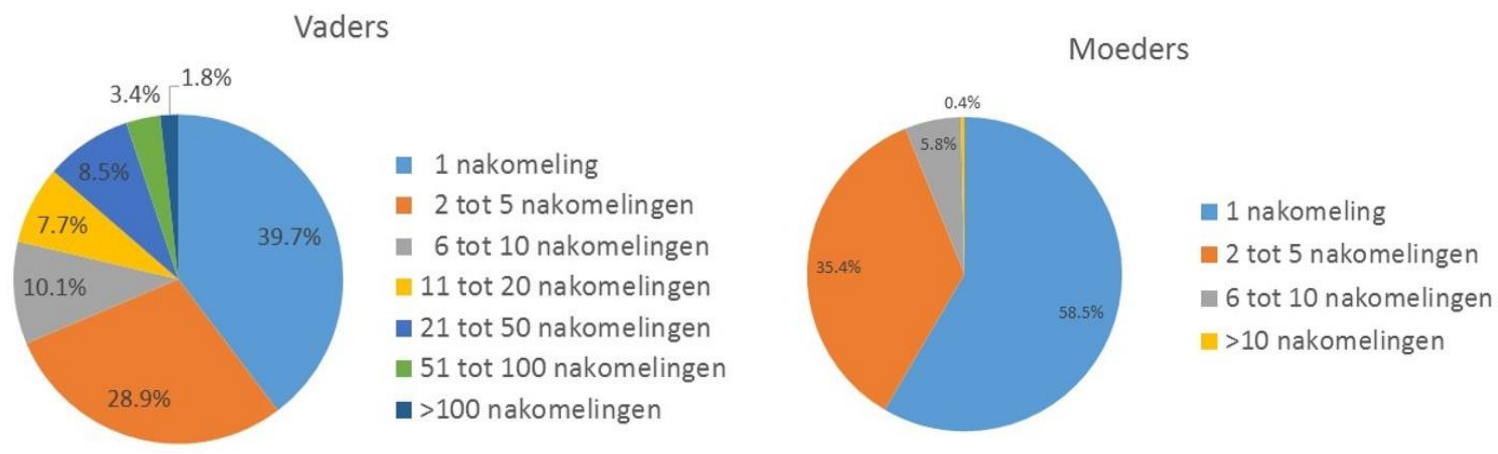

Figuur 3.1 Percentage vaders (links; totaal aantal vaders is 1.995) en moeders (rechts; totaal aantal moeders is 11.009) met een bepaald aantal nakomelingen.

\subsubsection{Stamboom compleetheid}

Stamboom compleetheid, het aantal generaties/voorouders in een stamboom dat bekend is, en geschatte inteeltpercentage gaan samen: bij een beperkte diepte van de stamboom zal het inteeltpercentage worden onderschat. Daarom is het van belang om inzicht te hebben in de compleetheid van de stamboom. De compleetheid van de stambomen van de Trekpaarden was ruim voldoende om de berekeningen te kunnen doen. 
Voor 93\% van de veulens geboren in 2017 waren $\geq 5$ generaties bekend, in 2010 was dit $86 \%$ van de veulens en in $200073 \%$ van de veulens (Figuur 3.2). Zoals verwacht, zijn meer generaties voorouders bekend van de meer recent geboren paarden.

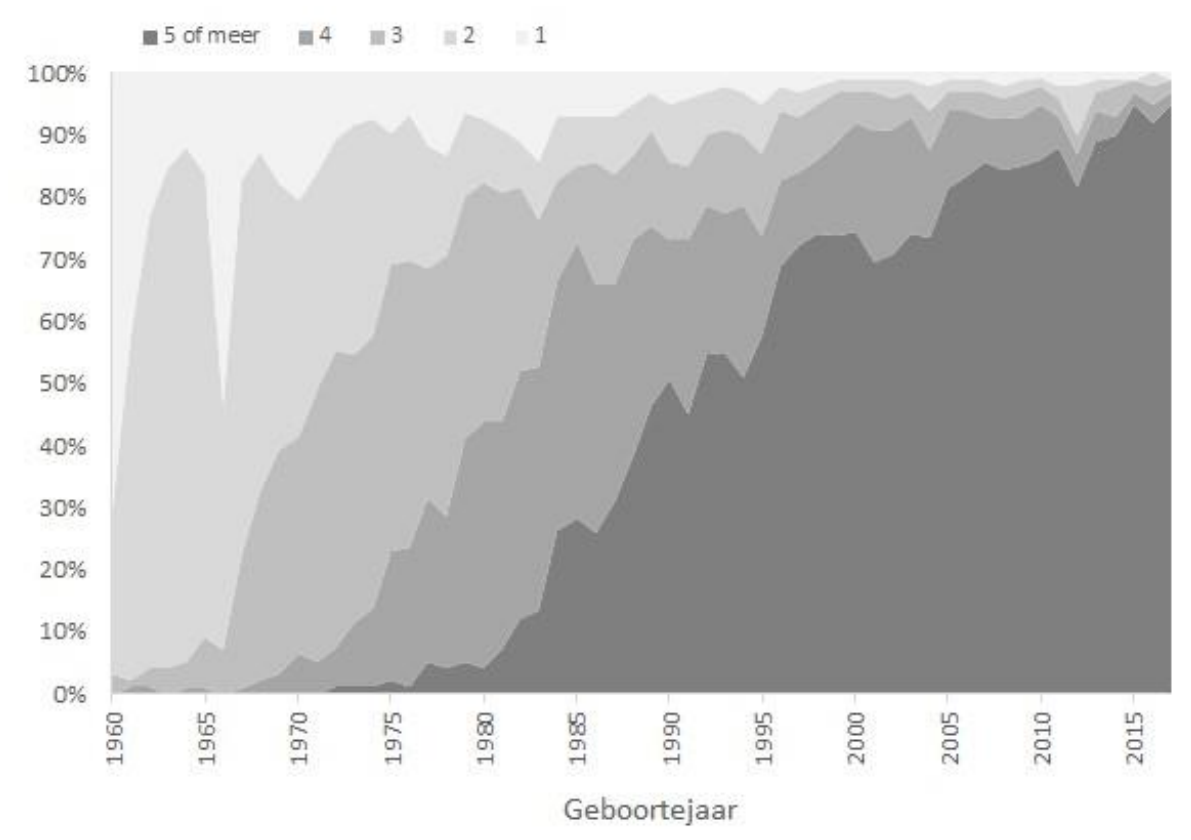

Figuur 3.2 Stamboom compleetheid: het aantal voorouderlijke generaties bekend per geboortejaar.

Het aantal generaties aan voorouders dat bekend is in een stamboom, is wat meer gespecificeerd in Figuur 3.3. Gemiddeld genomen waren voor een paard geboren in 2017 elf generaties aan voorouders bekend (Figuur 3.3), in 2010 betrof dit tien generaties terwijl dit er in 1960 twee waren.

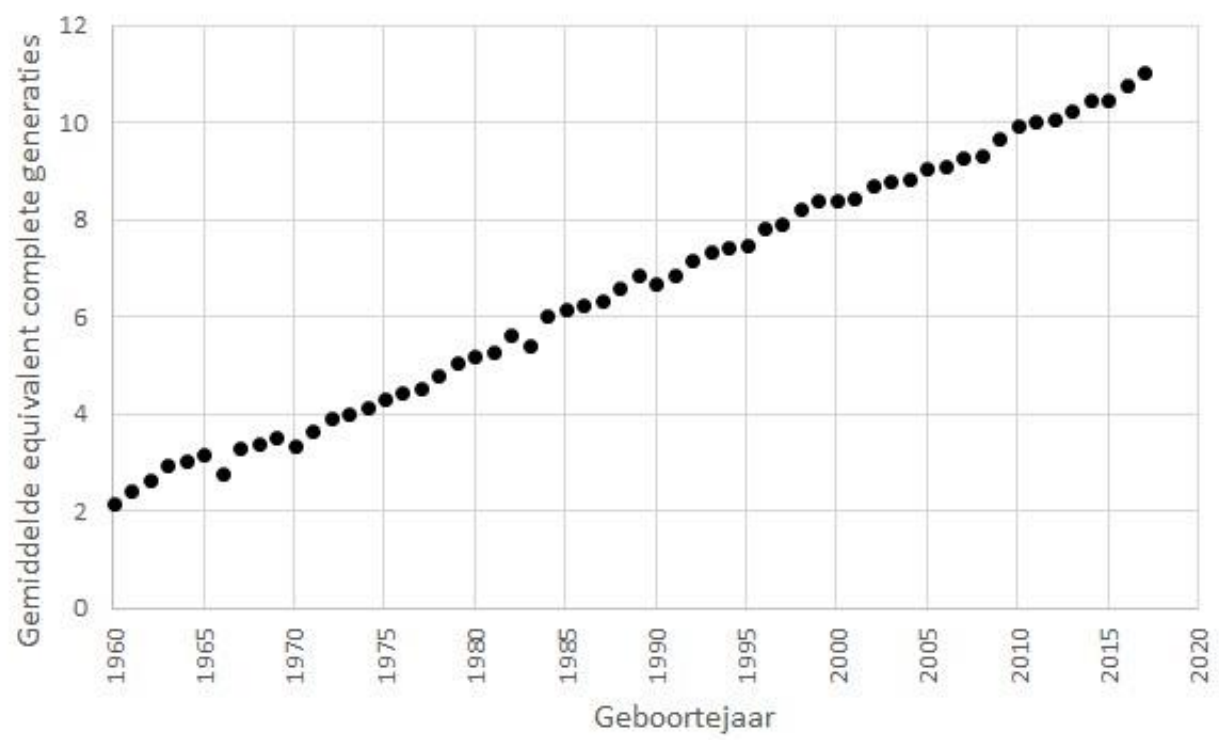

Figuur 3.3 Het gemiddelde equivalent complete generaties per geboortejaar.

Aan de hand van deze gegevens kunnen we concluderen dat de stamboom compleetheid ruim voldoende is om inzicht te krijgen in het inteeltpercentage en inteelttoename in de Trekpaardenpopulatie. 


\subsection{Populatiegrootte en inzet als fokdier}

Het geboortejaar van de 25.671 bij de KVTH geregistreerde Trekpaarden varieerde van 1909 tot 2017 (Figuur 4.4). Een opvallend hoog aantal veulens geboren in 1959 en 1966 werd geobserveerd. Mogelijk dat het geboortejaar van deze veulens (voorouders van de huidige generaties) niet digitaal geregistreerd was en op een willekeurig jaar is gezet. Vanaf 1996 werd een grote stijging geobserveerd in het aantal veulens geboren per jaar. Zeer aannemelijk is dat 1996 de start is van de (digitale) registratie van de stambomen van de Nederlandse Trekpaarden. Hoogstwaarschijnlijk vertegenwoordigen de veulens geboren voor 1996 vooral de voorouders van de huidige generaties.

Zorgwekkend is de daling in het aantal veulens per geboortejaar van gemiddeld 655 voor de periode 1996-2009 tot gemiddeld 390 voor de periode 2010-2016. Daarbij daalt het jaarlijks aantal geboren veulens dat wordt geregistreerd gestaag van 479 in 2010 tot 320 in 2016 (Figuur 3.4; registratie van veulens geboren in 2017 was ten tijde van ontvangst gegevens nog niet afgerond).

Ook wordt een daling geobserveerd in het aantal hengsten dat veulens voortbrengt per geboortejaar. In bijvoorbeeld 2010 werden 479 veulens geboren die afstamden van 70 hengsten, terwijl in 2016 nog maar 52 hengsten verantwoordelijk waren voor de in dat jaar geboren veulens (320).

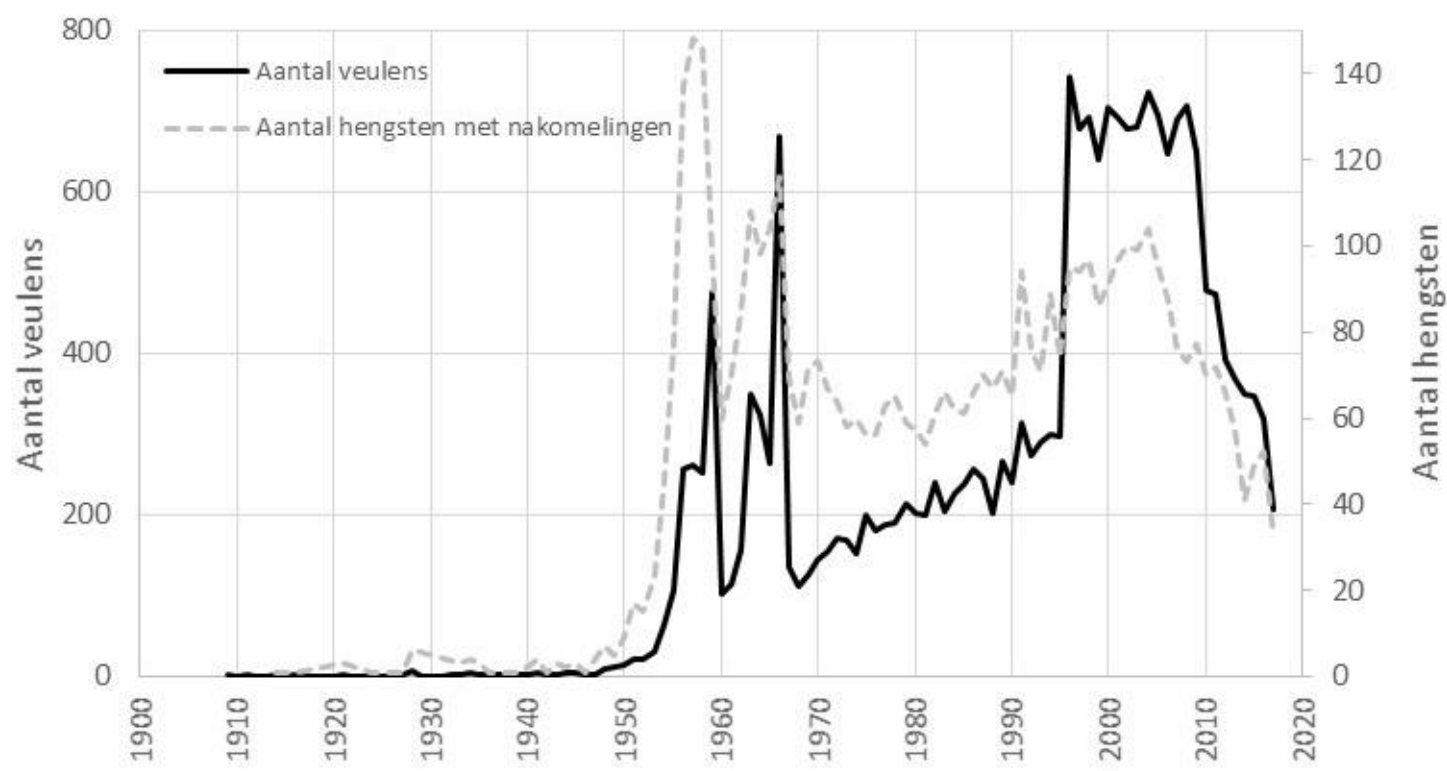

Geboortejaar paard

Figuur 3.4 Het aantal veulens en hengsten met nakomelingen per geboortejaar.

Het aantal en percentage merrieveulens dat op latere leeftijd wordt ingezet als fokmerrie (en dus nakomelingen voortbrengt) daalde gestaag van circa 50\% in 1996 tot circa $20 \%$ in 2013 (Figuur 3.5). Voor hengsten daalde dit percentage van circa 10\% in 1996 naar circa 3\% in 2013. 


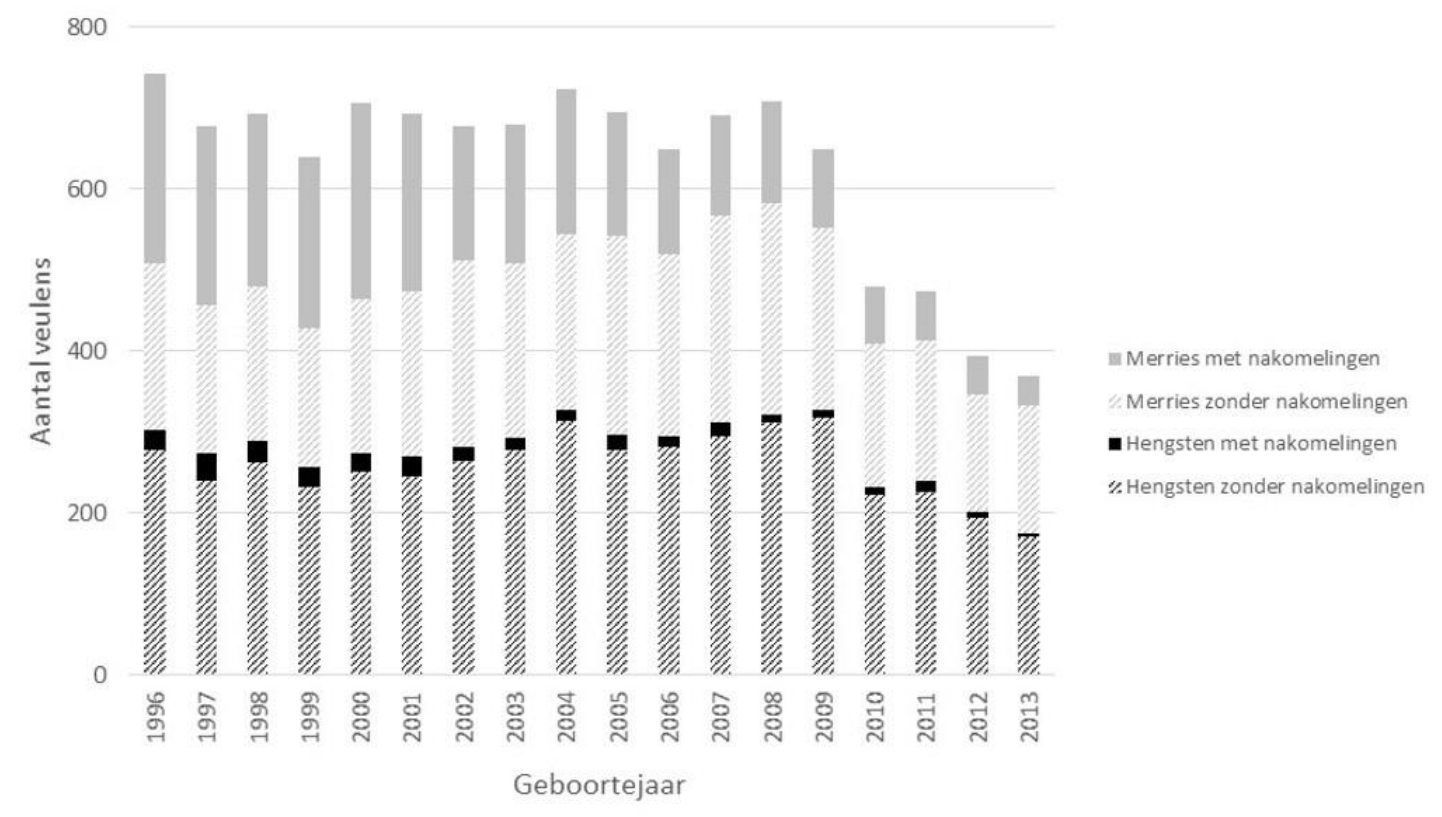

Figuur 3.5 Het aantal veulens (uitgesplitst naar geslacht) per geboortejaar dat op latere leeftijd wel of geen nakomelingen voortbracht.

Het gemiddelde aantal nakomelingen dat per hengst wordt geboren, bedroeg 30 . Voor merries lag dit aantal rond 3 nakomelingen gedurende de negentiger jaren (Figuur 3.6). Maar, het gemiddelde aantal nakomelingen per merrie en hengst nam af gedurende de meer recente jaren (Figuur 3.6). Dit heeft zeker te maken met de leeftijd van de paarden: meer recent geboren paarden kunnen/zullen in de toekomst nog actief ingezet worden in de fokkerij en daarmee nakomelingen voortbrengen. Daarnaast worden de sterke fluctuaties per geboortejaar bij de hengsten waarschijnlijk veroorzaakt door populaire en daardoor veel dekkende hengsten.

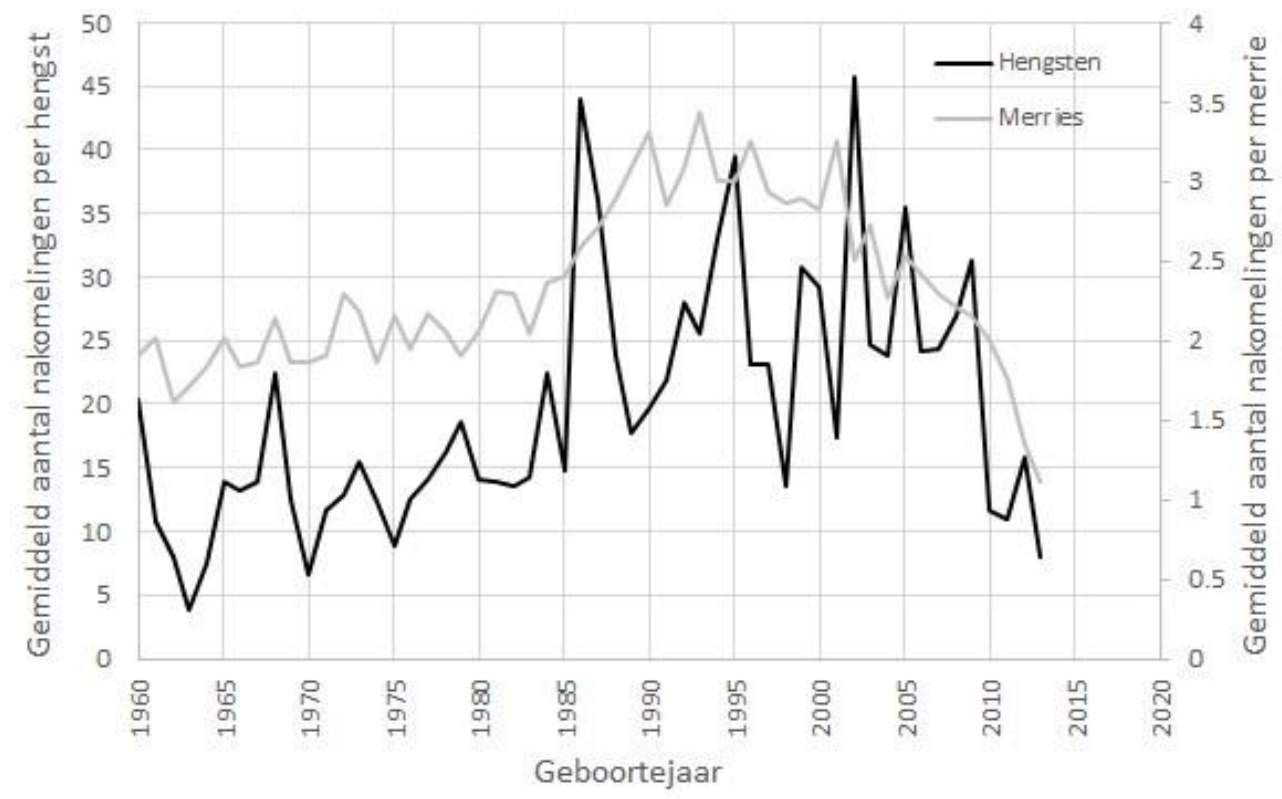

Figuur 3.6 Het gemiddelde aantal nakomelingen per hengst en merrie afgezet naar geboortejaar van het betreffende paard. 


\subsection{Generatie interval}

Het generatie interval, de gemiddelde leeftijd waarop ouders hun nakomelingen krijgen, bepaalt de snelheid van genetische vooruitgang door selectie in een populatie. De verdeling van de leeftijd van een ouder op het moment dat een nakomeling geboren wordt (Figuur 3.7), laat zien dat de hengsten meer op jongere leeftijd ( 4 tot 7 jaar) worden ingezet ten opzichte van de merries. Het berekende generatie interval aan vaders' zijde was inderdaad ietwat korter $(6,9$ jaar) dan die aan moeders' zijde (7,7 jaar). Het gemiddelde generatie interval in de populatie bedroeg 7,31 jaar, en is redelijk stabiel over de jaren heen (resultaten staan hier niet weergegeven).

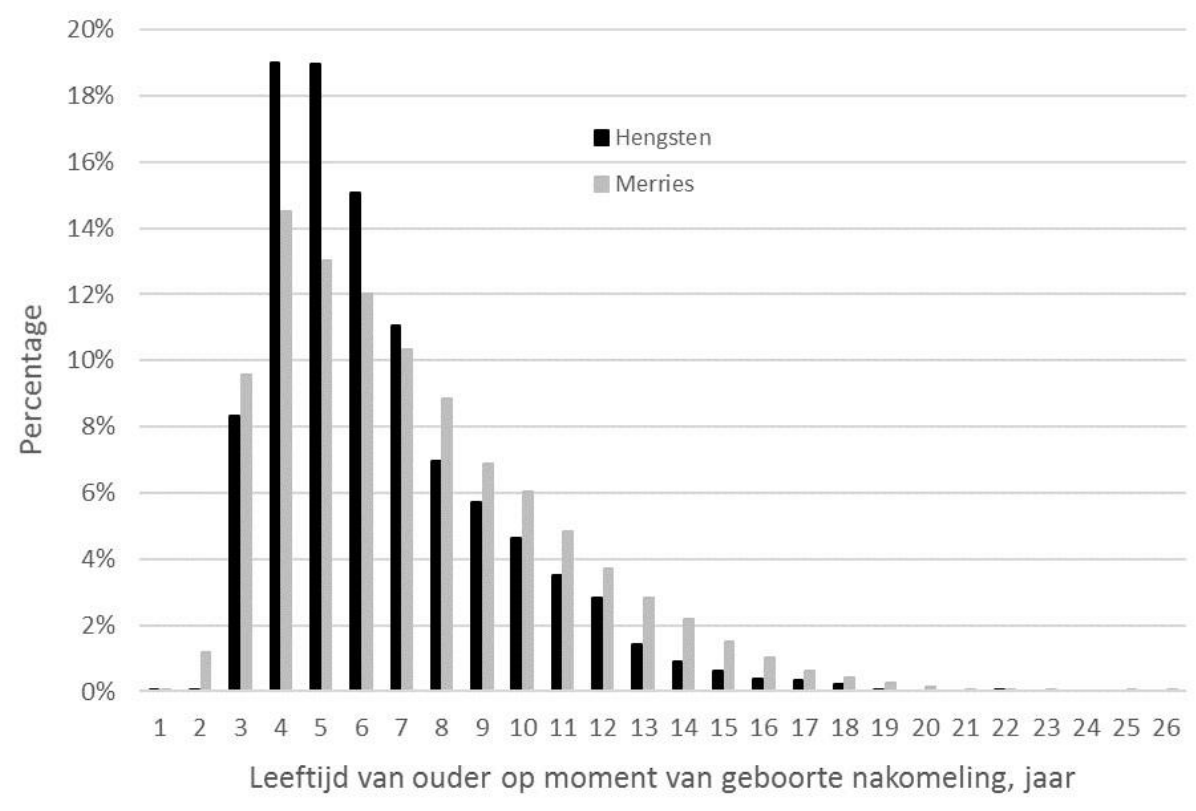

Figuur 3.7 Verdeling van de leeftijd van een ouder op het moment dat een nakomeling geboren wordt opgesplitst naar geslacht (alleen daadwerkelijke geboortejaren meegenomen, niet de geschatte geboortejaren).

Ten opzichte van andere paardenpopulaties is het generatie interval in Trekpaarden kort, aangezien gemiddeld vaak een generatie interval van 10 jaar gevonden wordt.

\subsection{Inteeltpercentage, verwantschap en -toename}

De toename in inteeltpercentage per generatie $(\Delta F)$ bedroeg $0,63 \%$ (Figuur 3.8) en overschrijdt daarmee de door de $F A O$ gestelde norm van $0,5 \%$ per generatie (FAO, 2013). $\triangle F$ is berekend met inachtneming van de gemiddelde inteeltpercentages vanaf geboortejaar 1960. Vanaf dit jaar werd een dermate aantal paarden per jaar geboren om een zinnig gemiddelde te kunnen berekenen. Een beperkt aantal paarden geboren in een specifiek jaar, vaak geobserveerd in de beginjaren van een populatie, kunnen leiden tot een vertekend beeld van $\Delta \mathrm{F}$.

De verwantschap tussen ouders is een voorspelling van de inteelt het jaar erop. De toename in gemiddelde verwantschap tussen de ouders die ingezet zijn in de fokkerij, laat gedurende de meest recente jaren een duidelijk ongewenste stijging zien en voorspelt daarmee een verdere toename in inteelt (Figuur 3.8). De toename in verwantschap is zowel tussen de dekhengsten onderling als ook tussen de fokmerries onderling (dus niet alleen veroorzaakt door een toenemende verwantschap tussen de hengsten). 


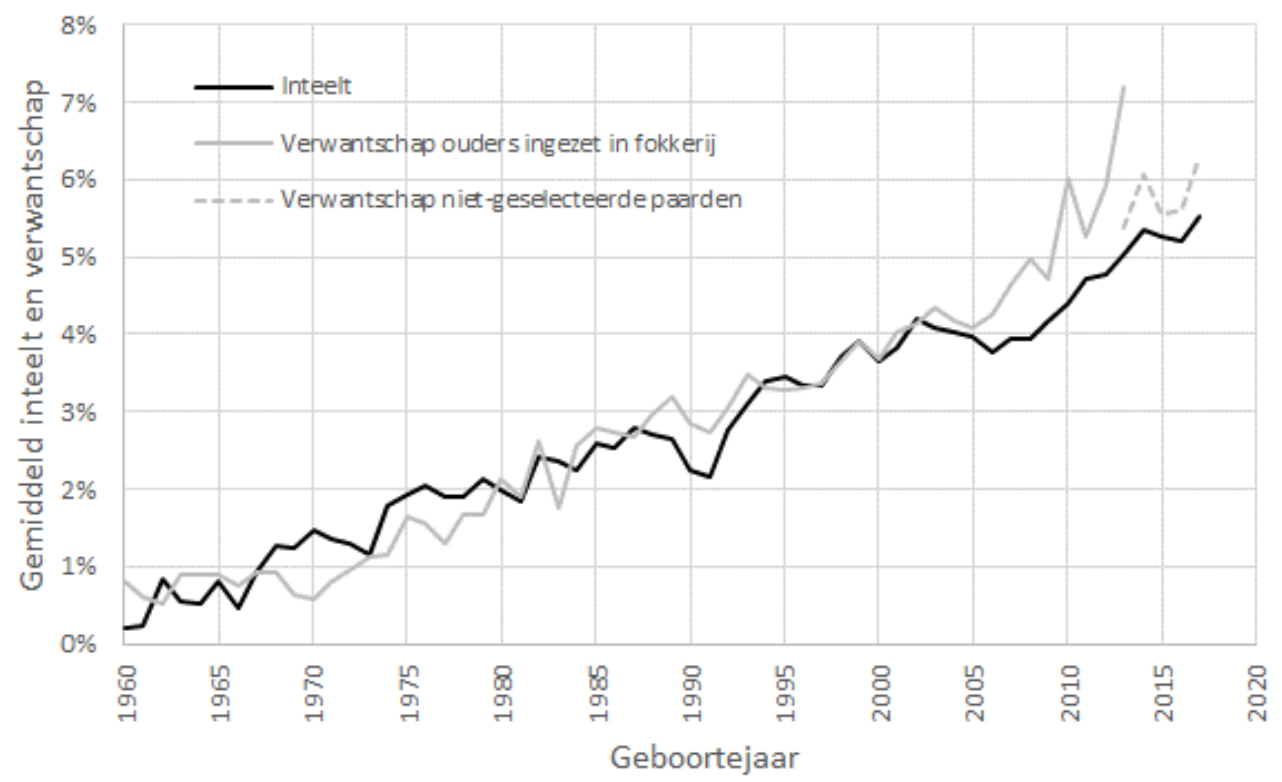

Figuur 3.8 Het gemiddelde inteeltniveau, verwantschap tussen ouders die zijn ingezet in de fokkerij en verwantschap tussen niet-geselecteerde paarden (in procenten) per geboortejaar.

De toename in inteelt en verwantschap tussen ouders is meer gespecificeerd in Figuur 3.9. Tot in de jaren 90 was de inteelttoename vrij constant rond de 0,6-0,7\% per generatie. Tussen 1997 en 2007 was de inteelt- en verwantschapstoename in de hele populatie laag, maar lag de verwantschapstoename van paarden die als ouder ingezet zijn vrij hoog (0,7\%). Dit duidt er op dat paarden die voor de fokkerij gebruikt zijn vaak verwanten zijn, dus veelal uit dezelfde families komen, of dezelfde hengst als (voor)vader hebben. Gedurende de laatste periode van tien jaar (2007-2017) was de toename in inteelt $(\Delta \mathrm{F})$ en verwantschap $(\Delta \mathrm{f})$ meer dan $>1 \%$ en ligt daarmee ruim boven de aanvaarde norm van $0,5 \%$ per generatie. Daarmee is het aannemelijk dat de negatieve gevolgen van inteelt optreden zoals een verhoogde kans op het ontstaan van erfelijke gebreken, inteeltdepressie als in verminderde vitaliteit en vruchtbaarheid, en op langere termijn het verloren gaan van bepaalde kenmerken.

\section{Inteelt en verwantschap}

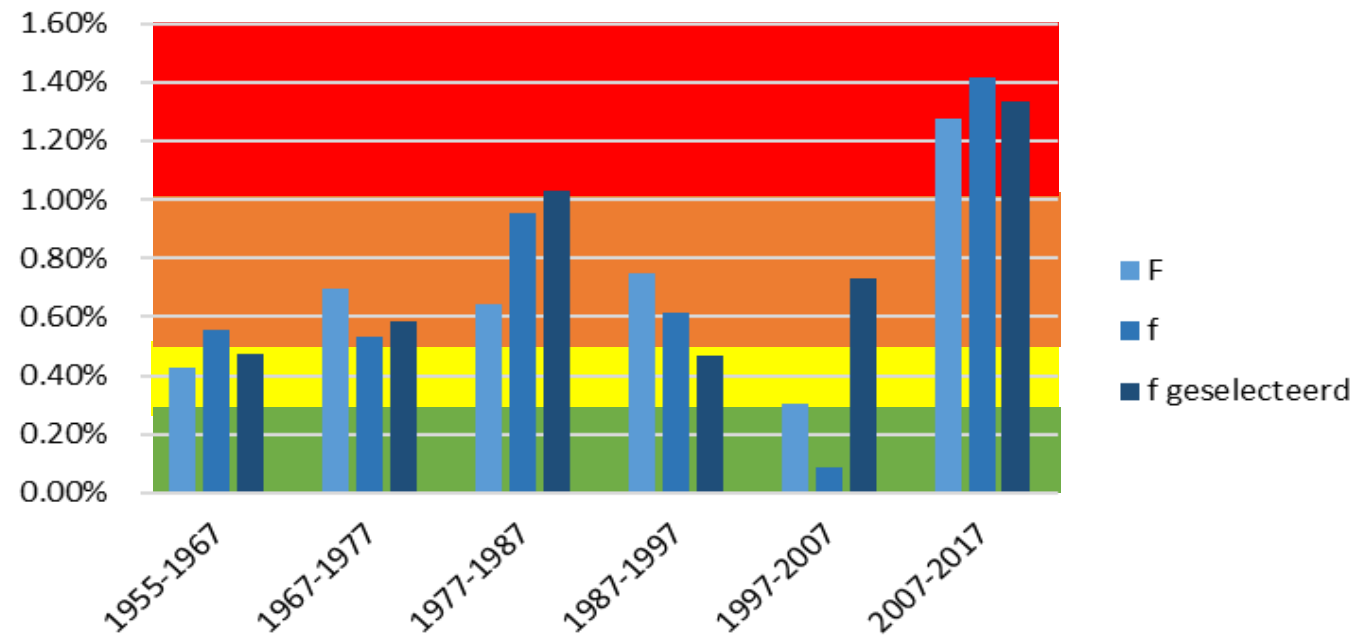

Figuur 3.9 De toename in inteelt $(F)$ en verwantschap $(f)$ in procent per generatie bepaald voor alle paarden en toename in verwantschap voor paarden geselecteerd als ouder ( $\mathrm{f}$ geselecteerd) voor periodes van tien jaar. Achtergrond: inschatting van het risico op genetische gebreken en inteeltdepressie van groen (veilig) tot rood (onaanvaardbaar hoog). 


\section{$4 \quad$ Advies genetisch beheer}

Op basis van de resultaten gevonden naar aanleiding van het doorlichten van de populatie op basis van afstammingsgegevens en simulaties van mogelijke aanpassingen in het fokprogramma, is er een advies gegeven over het genetisch beheer van de Nederlandse Trekpaardenpopulatie gericht op het beperken van de toename in inteelt (en daarmee behoud van genetische diversiteit in situ). De resultaten van deze simulaties en het bijbehorende advies wordt in dit hoofdstuk beschreven.

\subsection{Simulaties}

De populatie Trekpaarden is in de computer nagebootst met behulp van het programma GenManSim (Windig \& Oldenbroek) op basis van de populatiegegevens zoals geanalyseerd in hoofdstuk 3 . Deze basisgegevens staan vermeld in Tabel 4.1. Paren, geboorte van veulens en vervanging van fokdieren door veulens vindt elk jaar plaats, afhankelijk van het fokbeleid. Er is steeds 50 jaar fokkerij gesimuleerd. Het programma houdt de inteelt en verwantschap van de paarden bij en berekent de inteelttoename. Simulaties zijn per scenario 25 maal herhaald omdat door toeval (bijv. of er een mannelijk dan wel vrouwelijk veulen geboren wordt heeft steeds een kans van $50 \%$ ) de inteelt hoger of lager kan uitvallen. De volgende scenario's zijn gesimuleerd:

1) Huidige populatie en fokbeleid zonder beperkingen;

2) Beperking van het aantal veulens per dekhengst tot maximaal 20 per 2 jaar;

3) Beperking van het aantal veulens per dekhengst tot maximaal 10 per 2 jaar;

4) Inteelt minimaliseren. Voor elke merrie de minst verwante hengst zoeken zodat de veulens de laagst mogelijke inteelt zullen hebben;

5) Verwantschap beperken. Van ieder fokdier wordt de gemiddelde verwantschap met alle andere levende fokdieren berekend. Paarden met een hoger dan gemiddelde verwantschap worden uitgesloten van de fokkerij. Op deze manier worden paarden die al veel gebruikt zijn in de fokkerij, of met nauwe verwanten die veel gebruikt zijn, uitgesloten. Paarden uit nieuwe of weinig gebruikte 'bloedlijnen' krijgen daardoor een kans in de fokkerij.

Tabel 4.1 Populatiegegevens gebruikt voor de simulatie van de Trekpaardenpopulatie.

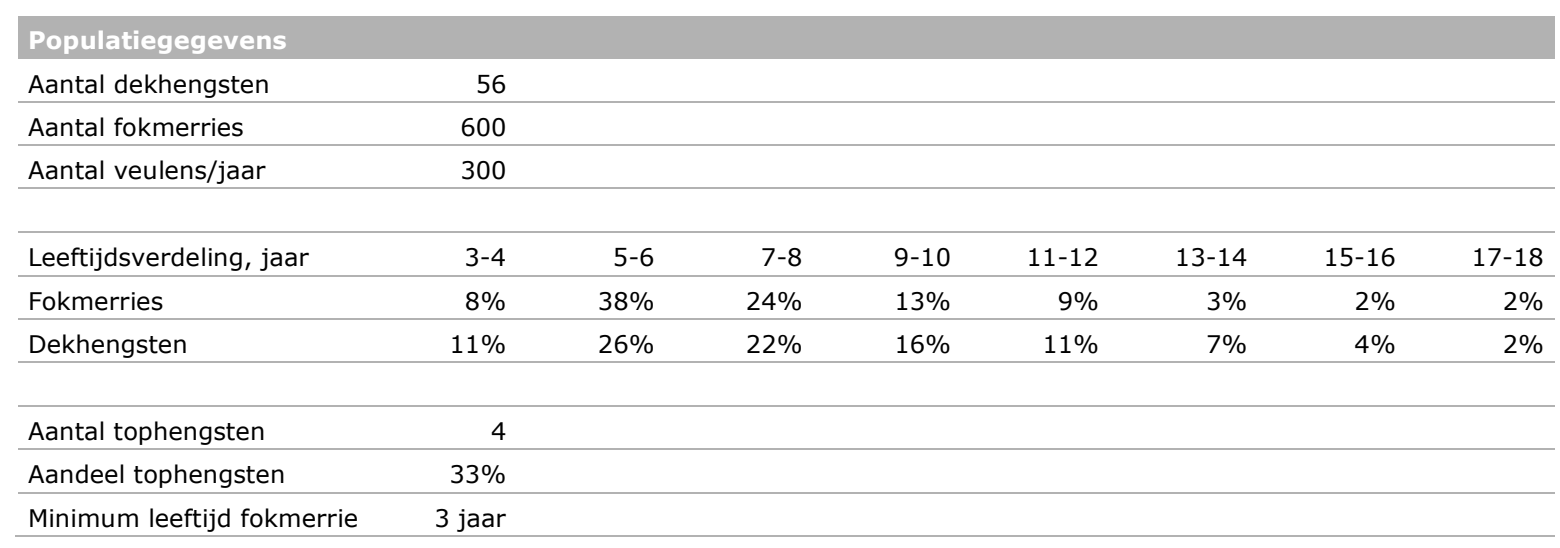

\subsubsection{Resultaten simulaties}

Als de huidige populatie gesimuleerd wordt dan komt de inteelttoename met 0,95\% per generatie net onder de $1 \%$ uit. Dat is iets lager dan de werkelijk geobserveerde populatie. Dit kan komen doordat in de simulaties niet is meegenomen dat populaire dekhengsten meer dan gemiddeld aan elkaar verwant kunnen zijn (uit dezelfde familie(s) komen). Dit zal echter geen invloed hebben op de simulaties waarin beleid op inteelt wordt gesimuleerd. 
Wanneer genetisch beheer wordt uitgevoerd, neemt de inteelttoename aanzienlijk af. Hoeveel hangt af van het beleid. Het meest effectief is het beperken van de verwantschap in de populatie. Hiermee neemt de inteelt af tot ruim onder een kwart procent per generatie (Tabel 4.2).

Tabel 4.2 Inteelttoename voor verschillend beleid bepaald met computersimulaties.

\begin{tabular}{llll} 
Scenario & Inteelttoename & Minimum & Maximum \\
Huidige populatie & $0,95 \%$ & $0,90 \%$ & $0,99 \%$ \\
\hline Dekbeperking 20 & $0,35 \%$ & $0,33 \%$ & $0,37 \%$ \\
\hline Dekbeperking 10 & $0,18 \%$ & $0,17 \%$ & $0,20 \%$ \\
\hline Minimaliseren inteelt & $0,25 \%$ & $0,24 \%$ & $0,27 \%$ \\
\hline Beperken verwantschap & $0,13 \%$ & $0,11 \%$ & $0,14 \%$ \\
\hline
\end{tabular}

Minimaliseren van de inteelt is in eerste instantie het meest effectief (Figuur 4.1). Maar, na rond de 18 jaar neemt de inteelt dan weer sneller toe. Dat komt omdat aanvankelijk voor iedere merrie niet of weinig verwante hengsten kunnen worden gevonden, maar op een gegeven moment zijn de weinig verwante hengsten allemaal gebruikt en loopt de inteelt weer sneller op. Wordt de inteelttoename over de laatste 25 jaar berekend, dan komt die op 0,40\% uit per generatie.

Dekbeperkingen hebben ook een groot effect, maar wel minder dan het beperken van de verwantschap. Het effect van dekbeperkingen is vooral sterk omdat in de huidige populatie een beperkt aantal dekhengsten (4) een groot aandeel hebben in de volgende generatie (33\% van alle fokmerries dekt). Met een dekbeperking wordt dit voorkomen.

\section{Inteelt niveau}

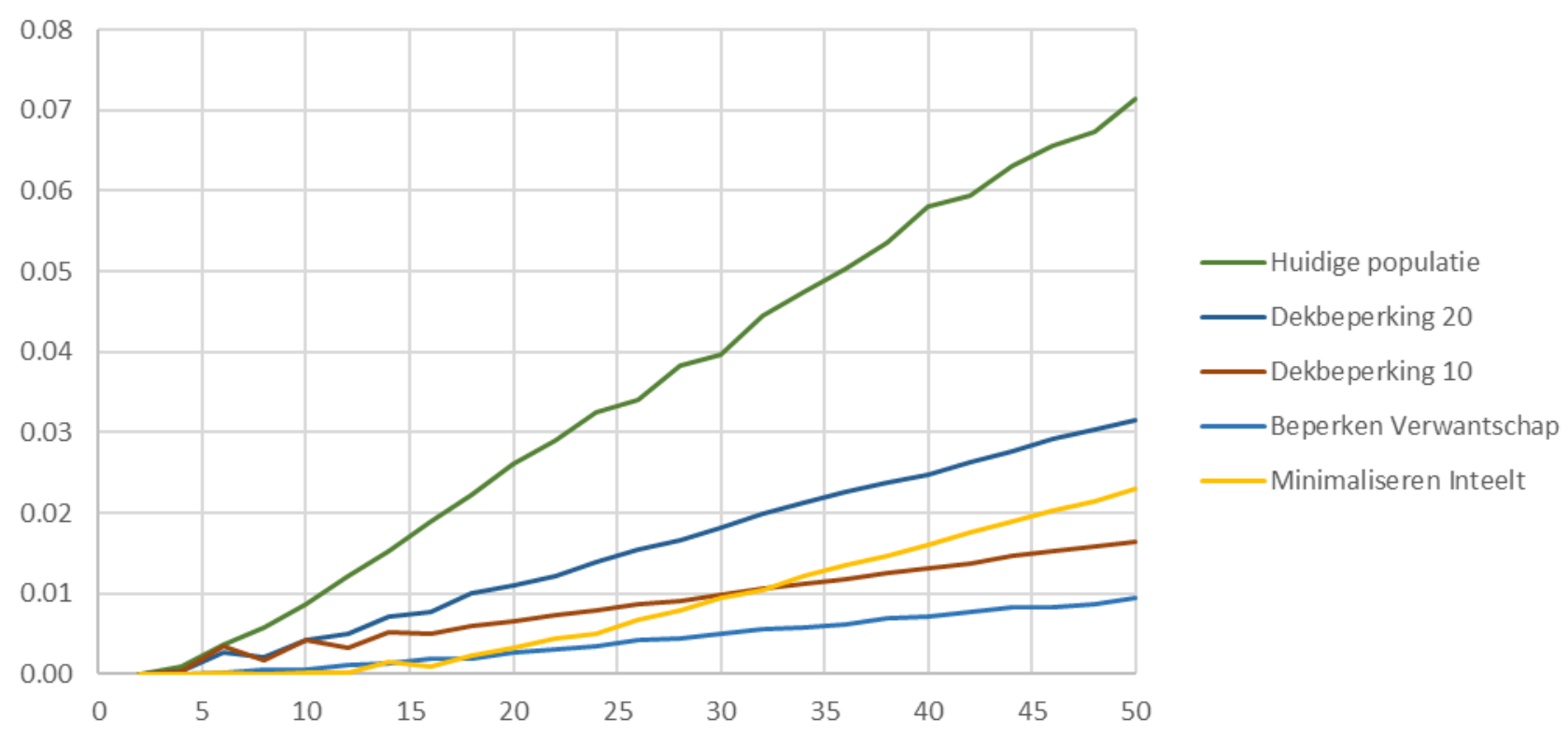

Figuur 4.1 De toename in inteelt bij verschillend beleid in de komende 50 jaar, bepaald met computersimulaties.

\subsection{Advies}

De simulaties laten zien dat door genetisch beheer het mogelijk is de inteelttoename in de Nederlandse Trekpaardenpopulatie drastisch terug te dringen. In de huidige populatie is de inteelttoename te hoog. Er dient dus beleid gericht op het terug dringen van de inteelttoename gevoerd te worden. Alle gesimuleerde maatregelen hebben een positief effect op het terugdringen van inteelt, maar sturen op verwantschap is het meest effectief. 


\section{$5 \quad$ Advies aanvulling genenbank}

Eind 2017 was sperma van 28 verschillende dekhengsten opgeslagen in de genenbank. Middels onderzoek aan afstammingsgegevens zijn genetisch interessante Trekpaardhengsten geïdentificeerd die kandidaat zijn voor aanvulling van de genenbank collectie voor het Nederlandse Trekpaard.

\subsection{Kandidaat dekhengsten voor aanvulling genenbank}

Kandidaat dekhengsten voor aanvulling van de genenbank werden geïdentificeerd met behulp van de dataset toegezonden door het KVTH. In de dataset werd aangegeven welke hengsten actief waren in het dekseizoen van 2017. Hengsten die voorheen actief waren in dekdienst maar in 2017 niet zijn ingezet, konden ook worden geïdentificeerd. Volgens de dataset zouden deze hengsten nog in leven zijn, wat ook aannemelijk is aan de hand van de leeftijd van deze hengsten. In 2017 waren 30 hengsten actief en voorheen 37 hengsten (exclusief de dekhengsten waarvan al sperma is veiliggesteld in de genenbank). Deze 67 hengsten zijn kandidaten voor aanvulling van de genenbank met nieuwe hengsten.

Daarnaast was het aantal doses (en kwaliteit) sperma van een aantal hengsten waarvan reeds materiaal in de genenbank is veiliggesteld, soms beperkt. Aanvulling van het aantal doses sperma van deze hengsten behoorde ook tot de mogelijkheden voor uitbreiding van de genenbank collectie voor Trekpaarden.

\subsection{Verwantschap tussen (fok)populatie en kandidaat dekhengsten voor aanvulling genenbank}

De verwantschap tussen de huidige (fok)populatie en kandidaat dekhengsten voor aanvulling van de genenbank collectie voor het Nederlands Trekpaard werd vastgesteld om te kijken hoe gerelateerd de verschillende groepen en individuen zijn. Op deze manier werden hengsten geïdentificeerd die interessant zijn voor aanvulling van de collectie en/of waarvoor gebruik in de dekdienst gestimuleerd kan worden in verband met een gemiddeld lagere genetische verwantschap met de (fok)populatie. Een lagere verwantschap tussen de ouders houdt in dat het inteeltpercentage van de nakomeling ook lager is, want het inteeltpercentage van de nakomeling $=1 / 2 x$ de verwantschap tussen de ouders. En, hengsten met een lager dan gemiddelde verwantschap met de huidige (fok)populatie zijn waardevol met het oog op bloedspreiding.

\subsubsection{Verwantschap tussen groepen binnen het Nederlands Trekpaard}

De gemiddelde verwantschap (average numerator relationships) binnen en tussen verschillende groepen werd berekend om inzicht te krijgen in de mate van verwantschap binnen en tussen deze groepen (zie Tabel 3.1). De populatie werd opgedeeld in de volgende vijf groepen:

- de potentiële (fok)merriepopulatie bestaande uit merries geboren in 2014, 2015, 2016 en 2017 (jonge merries nog zonder nakomeling, maar potentieel fokmerrie) en merries geboren tussen 2006 en 2013 met minimaal één nakomeling (de meest recente generatie fokmerries; FOKMERRIE);

- $\quad$ hengsten waarvan reeds sperma is opgeslagen in de genenbank (GENENBANK);

- dekhengsten die ingezet zijn gedurende de dekdienst van 2017 (DEKHENGST2017);

- dekhengsten die voorheen actief waren (en als het goed is, nog in leven; DEKHENGST);

- $\quad$ alle overige Trekpaarden (TP).

De hengsten waarvan reeds sperma in de genenbank is opgeslagen, hebben gemiddeld genomen de laagste verwantschap met de fokmerriepopulatie, dekhengsten uit 2017 en voorgaande jaren en tevens de rest van de Trekpaardenpopulatie (zie Tabel 5.1). Deze hengsten zijn dus het minst 
gerelateerd aan de in leven zijnde (in situ) populatie. Inzet van deze hengsten zou potentieel kunnen bijdragen aan het in stand houden, of mogelijk het verbreden van de genetische diversiteit binnen de populatie, of anders gezegd bijdragen aan bloedspreiding.

Tabel 5.1 Gemiddelde verwantschap binnen en tussen de gedefinieerde groepen. De gemiddelde verwantschap kan variëren van 0 tot 1 , waarbij 0 aangeeft dat paarden ongerelateerd zijn (richting donkergroen) en 1 dat paarden volledig gerelateerd zijn (richting rood).

\begin{tabular}{lrrrr} 
& FOKMERRIE & GENENBANK & DEKHENGST2017 & DEKHENGST \\
FOKMERRIE & 0,104 & 0,096 & 0,109 & 0,101 \\
\hline GENENBANK & & 0,114 & 0,098 & 0,055 \\
\hline DEKHENGST2017 & & 0,146 & 0,050 \\
\hline DEKHENGST & & & 0,104 \\
\hline TP & & & 0,127 \\
\hline
\end{tabular}

FOKMERRIE = de potentiële fokmerriepopulatie bestaande uit merries geboren in 2014, 2015, 2016 en 2017 en merries geboren tussen 2006 en 2013 met minimaal één nakomeling; GENENBANK = hengsten waarvan reeds sperma is opgeslagen in de genenbank; DEKHENGST2017 = dekhengsten die ingezet zijn gedurende de dekdienst van 2017; DEKHENGST = dekhengsten die voorheen actief waren (en als het goed is, nog in leven); TP = alle overige Trekpaarden.

De gemiddelde verwantschap tussen de in 2017 aangeboden dekhengsten is het hoogst $(0,146)$. Dit houdt in dat gemiddeld genomen deze hengsten meer aan elkaar gerelateerd zijn dan bijvoorbeeld de dekhengsten die voorheen in de dekdienst werden ingezet $(0,127)$. Anders gezegd, de beperktere spreiding in bloedvoering tussen de dekhengsten ingezet in 2017 is ongewenst, aangezien het waarschijnlijk zal resulteren in een toekomstige toename in inteelt (in overeenstemming met de resultaten beschreven in paragraaf 3.4 Inteeltpercentage, verwantschap en -toename).

\subsubsection{Verwantschap tussen individuele hengsten en de huidige (fok)populatie}

Omdat de verwantschap tussen de ouders het inteeltpercentage van de nakomeling bepaalt (het inteeltpercentage van de nakomeling = $1 / 2 x$ de verwantschap tussen de ouders) en de gemiddelde verwantschap van een hengst met de huidige (fok)populatie zijn waarde bepaalt qua bijdrage aan bloedspreiding, is voor elke individuele hengst de verwantschap met de huidige (fok)populatie berekend. Een hengst met een lage verwantschap met de (fok)populatie kan bijdragen aan het beperken van de inteelttoename en daarmee het in stand houden, of mogelijk het verbreden van de genetische diversiteit in de populatie, of anders gezegd bloedspreiding inbrengen. Een hengst met een hoge verwantschap met de (fok)populatie daarentegen niet. Een dergelijk hengst heeft meer voorouder(s) gemeenschappelijk met de huidige (fok)populatie en/of heeft zelf veel nakomelingen die tot de (fok)populatie behoren ten opzichte van een hengst met een lage verwantschap.

Een redelijke variatie werd geobserveerd in de gemiddelde verwantschap van een individuele hengst met de (fok)populatie: van 0,048 (4,8\%) tot 0,144 (14,4\%; zie Bijlage 2). Een hengst met een lager dan gemiddelde verwantschap met de (fok)populatie en nog een beperkt aantal nakomelingen is interessant om te promoten voor gebruik in de levende populatie (in situ), omdat het bloed van deze hengst nog weinig voorkomt in de populatie. Kanttekening hierbij is dat alleen naar de waarde van de hengst qua bloedspreiding wordt gekeken, andere kwaliteiten en fokprestaties zijn hierbij niet meegenomen. Dekhengsten die in 2017 zijn ingezet voor de dekdienst, nog een beperkt aantal nakomelingen hebben, lager dan gemiddeld verwant zijn aan de (fok)populatie en nog beschikbaar zijn in 2018, zijn Unik de Lichereau, Stan van Malderen van Vlaams Brabant, Jazz van de Wilgenhoeve, Leander van de Boterhoeve, Landor van de Boterhoeve, Fonne van de Stock, Sam van de Vinkebossen, Cassanova van de Kannelust en Dorus van de Molenhoeve (zie Bijlage 2). Hengsten die zijn gebruikt in de dekdienst voor 2017, met een lager dan gemiddelde verwantschap en een beperkt aantal nakomelingen zijn helaas niet meer beschikbaar (geëxporteerd of overleden).

Eenzelfde overzicht werd geproduceerd voor de hengsten waarvan reeds sperma is opgeslagen in de genenbank. De verwantschap tussen deze hengsten en de (fok)populatie varieerde eveneens. De verwantschap tussen Udo van de Zaaidijk en ook Roel van de Lindehof en de huidige (fok)populatie was het groots (respectievelijk 0,153 en 0,156; zie Bijlage 3), terwijl de verwantschap tussen Eugeen van de Veldvoort en ook Texas d'Aywiers en de huidige (fok)populatie het laagst is (respectievelijk 
0,029 en 0,048 ). Inzet van hengsten met een lage verwantschap met de (fok)populatie zou bij kunnen dragen aan het in stand houden of zelfs het verbreden van de genetische diversiteit in de Trekpaardenpopulatie. Lager dan gemiddeld verwant aan de (fok)populatie zijn: Eugeen van de Veldvoort, Texas d'Aywiers, Harry van de Bomlozeput, Twan van de Schaijksehoek, Baron van $t$ Zeegat, Marco van het Koyennehof, Hannes van de Capreton, Gillis van de Heirhoeve, Paul van $t$ Clerckshof, Dylan van Hoeve Ruth, Bart van Wienenhof, Igor van den Ossenberg en Robert van $t$ Clerckshof. Weloverwogen inzet van deze hengsten in de huidige populatie zou kunnen bijdragen aan het in stand houden of zelfs het verbreden van de genetische diversiteit in de Trekpaardenpopulatie. Wederom hierbij de kanttekening dat alleen naar de waarde van de hengst wordt gekeken qua bloedspreiding, andere kwaliteiten en fokprestaties zijn hierbij niet meegenomen.

\subsection{Geselecteerde dekhengsten voor aanvulling genenbank}

Bijlage 4 bevat ter informatie de onderlinge verwantschap tussen de hengsten waarvan eind 2017 reeds sperma was veiliggesteld in de genenbank. De genenbank collectie bevat een tweetal vaderzoon combinaties en eveneens twee halfbroers. Met de huidige aantallen (materiaal van 28 hengsten), de aanwezige relaties tussen de hengsten (zie bijlage 4) en ook veelal het beperkte aantal veiliggestelde doses is voor de Trekpaarden nog geen sprake van een core collectie. In 2018 is daarom ingezet op het aanvullen van de genenbank collectie voor de Nederlandse Trekpaarden.

De berekende verwantschap tussen de kandidaat dekhengsten en de (fok)populatie beschreven in paragraaf 5.2 liet zien dat er een grote variatie is in deze verwantschap: hengsten met een duidelijk lager maar ook hoger dan gemiddelde verwantschap werden geïdentificeerd. Hengsten met een lage verwantschap met de (fok)populatie zouden een aanvulling kunnen zijn voor de genenbank collectie. Diverse criteria zoals het reeds voortgebrachte aantal nakomelingen en de verwantschap tussen de kandidaat dekhengsten werden meegenomen door het programma GenCont voor de identificatie van dekhengsten waarvan sperma in de genenbank zou moeten worden veiliggesteld.

Omdat het aantal doses van een redelijk deel van de hengsten waarvan reeds sperma is veiliggesteld in de genenbank beperkt is, werden ook deze hengsten (met het aantal doses) meegenomen in de afweging door het programma GenCont.

Tabel 5.2 Geselecteerde hengsten voor uitbreiding genenbank collectie Nederlands Trekpaard.

\begin{tabular}{|c|c|c|c|}
\hline Naam & Paardcode & Aantal doses in genenbank & Geboortejaar \\
\hline Fonne van de Stock & P-057093 & & 2008 \\
\hline Unik de Lichereau & P-060789 & & 2009 \\
\hline Stan van Malderen van Vlaams Brabant & P-063984 & & 2013 \\
\hline Amigo van Sluishoek & P-010078 & & 2004 \\
\hline Tim van de Wilgenhoeve & P-018598 & & 2007 \\
\hline Bart van Wienenhof & P-011271 & 17,8 & 2005 \\
\hline Bram van de Ruiting & P-018584 & 34,7 & 2007 \\
\hline Gillis van de Heirhoeve & P-008443 & 4,5 & 2000 \\
\hline Lars van de Doore Plas & P-064955 & 3,1 & 2014 \\
\hline Marius van Luchteren & P-064983 & 10,1 & 2014 \\
\hline Paul van t Clerckshof & P-059643 & 17,2 & 2008 \\
\hline
\end{tabular}

Bij navraag aan het KVTH bleek dat 9 van de 28 hengsten waarvan reeds materiaal in de genenbank is veiliggesteld, nog beschikbaar zouden zijn. Van de 67 kandidaat hengsten waarvan nog geen materiaal is veiliggesteld, zijn er 23 beschikbaar (in leven en in Nederland aanwezig). In de analyse werden deze 9 plus 23 beschikbare kandidaten meegenomen. 
Voor de hengsten waarvan reeds materiaal in de genenbank is veiliggesteld, werd verhoudingsgewijs aangegeven hoeveel doses sperma al aanwezig zijn (cprev). Gestelde aanname hierbij is dat we reeds een bepaald percentage van onze core collectie hebben verzameld. Hoe hoger dit percentage, des te minder hengsten er geselecteerd werden: 7 hengsten bij 50\%, 8 hengsten bij 40\% en 12 hengsten bij $25 \%$. Het merendeel van de geselecteerde hengsten betrof hengsten waarvan reeds (beperkt) materiaal aanwezig is in de genenbank, respectievelijk 6 uit 7 bij 50\%, 7 uit 8 bij $40 \%$ en 8 uit 12 bij $25 \%$.

Wanneer het reeds aanwezige materiaal in de genenbank geen rol speelde bij de selectie van de kandidaten (cprev $=0$ voor alle hengsten), werden 19 hengsten geselecteerd waarvan van 8 reeds (beperkt) materiaal aanwezig is in de genenbank.

Wanneer het maximale aantal hengsten dat wordt geselecteerd op 15 werd gezet in verband met beperkingen op gebied van beschikbare tijd en budget, werden de hengsten gepresenteerd in Tabel 5.2 gekozen voor uitbreiding/aanvulling van de genenbankcollectie voor het Nederlandse Trekpaard; de selectie op basis waarvan eigenaren zijn benaderd. 


\section{Conclusies en aanbevelingen}

\subsection{Aanleiding, doelstelling en analyses}

Onderdeel van het instandhoude van zeldzame rassen is het van tijd tot tijd monitoren van ontwikkelingen binnen een ras, omdat de beperkte grootte risico's met zich meebrengt op het gebied van inteelt. Aan de hand van de bevindingen van het monitoren geeft het CGN advies aan stamboeken en rasorganisaties om een ras op een gezonde manier in stand te houden. In afstemming met het KVTH, in het licht van de door García et al. (2009) berekende inteelttoename van 0,5\% per generatie en de sindsdien verstreken jaren, is de Nederlandse Trekpaardenpopulatie in 2018 wederom doorgelicht.

Doelstelling van het onderzoek was:

1. Het doorlichten van de Nederlandse Trekpaardenpopulatie om te onderzoeken hoe de huidige populatie er voor staat qua grootte, inteelt en verwantschap;

2. Een advies geven over het genetisch beheer van de Nederlandse Trekpaardenpopulatie;

3. Het identificeren van genetisch interessante Trekpaardhengsten voor aanvulling van de genenbank collectie.

Afstammingsgegevens van 25.671 Trekpaarden (de door het KVTH in het digitale systeem geregistreerde paarden) werden geanalyseerd met behulp van diverse specifieke software programma's om de beoogde doelstelling te behalen.

\subsection{Het doorlichten van de Nederlandse Trekpaardenpopulatie}

Een duidelijke afname in het aantal veulens dat wordt geboren per jaar werd geobserveerd. Van 649 veulens in 2009 (en voorgaande jaren), naar 320 in 2016. Daarbij daalt het percentage veulens dat op latere leeftijd wordt ingezet als dekhengst of fokmerrie in de fokkerij ook gestaag. In 1996 bedroeg dit nog circa $50 \%$ van de merrieveulens en $10 \%$ van de hengstveulens, maar daalde naar respectivelijk circa $20 \%$ en $3 \%$ in 2013 . Een daling werd eveneens geobserveerd in het aantal dekhengsten dat zorgt voor veulens in een jaar, waar in bijv. 2017 nog 70 hengsten verantwoordelijk waren voor de geboren veulens, waren dit er in 2016 nog maar 52.

Het generatie interval, de gemiddelde leeftijd van de ouders waarop nakomelingen worden geboren die bijdragen aan de volgende generatie, is beduidend lager dan in andere paardenrassen. Gemiddeld genomen bedraagt een generatie interval 10 jaar, waar dit slechts 7,3 jaar bedroeg in de Nederlandse Trekpaardenpopulatie. Dekhengsten worden vooral op jonge leeftijd ingezet, waarbij driekwart van de vaders 7 jaar of jonger is. Een verklaring kan niet direct gevonden worden. Mogelijk zijn er problemen met levensduur in de Trekpaardenpopulatie?

Vanaf 2009 is een (ongewenste) stijgende trend te zien met betrekking tot de verwantschap tussen de paarden die ingezet worden voor de fokkerij: de beschikbare dekhengsten en fokmerries zijn sterker aan elkaar gerelateerd dan voorheen wat zal resulteren in een (snellere) toename in inteelt. De berekende inteelttoename ligt boven de door de FAO gestelde norm van 0,5\% per generatie.

De geobserveerde sterke toename in inteelt en verwantschap in de meest recente generatie, het steeds kleiner worden van de populatie én fokpopulatie, en een redelijke invloed van een beperkt aantal populaire dekhengsten in de populatie zijn zeer heldere bevindingen die aangeven dat acties noodzakelijk zijn om het Nederlandse Trekpaard op een gezonde manier in stand te houden. 


\subsection{Advies genetisch beheer}

De inzet van dekhengsten lager dan gemiddeld verwant aan de (fok)populatie zou kunnen bijdragen aan het inperken van de inteelttoename. Hengsten die dit jaar beschikbaar zijn, lager verwant en met nog een beperkt aantal nakomelingen, zijn: Unik de Lichereau, Stan van Malderen van Vlaams Brabant, Jazz van de Wilgenhoeve, Leander van de Boterhoeve, Landor van de Boterhoeve, Fonne van de Stock, Sam van de Vinkebossen, Cassanova van de Kannelust en Dorus van de Molenhoeve. Kanttekening hierbij is dat alleen naar de waarde van de hengst qua bloedspreiding wordt gekeken, andere kwaliteiten en fokprestaties zijn hierbij niet meegenomen.

Gebruik van sperma dat is veiliggesteld in de genenbank behoort ook tot de mogelijkheden om bloedspreiding in de populatie in te brengen. Hengsten met een lager dan gemiddelde verwantschap met de (fok)populatie, zijn (in volgorde van laag naar gemiddeld verwant): Eugeen van de Veldvoort, Texas d'Aywiers, Harry van de Bomlozeput, Twan van de Schaijksehoek, Baron van t Zeegat, Marco van het Koyennehof, Hannes van de Capreton, Gillis van de Heirhoeve, Paul van t Clerckshof, Dylan van Hoeve Ruth, Bart van Wienenhof, Igor van den Ossenberg en Robert van t CLerckshof. Het beschikbare aantal doses is echter soms erg beperkt. Wederom spreken we hier alleen over de waarde die de hengst kan leveren qua bloedspreiding. Andere kwaliteiten en fokprestaties zijn niet meegenomen.

De computersimulaties laten zien dat door genetisch beheer het mogelijk is de inteelttoename in de Nederlandse Trekpaardenpopulatie drastisch terug te dringen. In de huidige populatie is de inteelttoename te hoog. Er dient dus beleid gericht op het terug dringen van de inteelttoename gevoerd te worden. Alle gesimuleerde maatregelen hebben een positief effect op het terug dringen van inteelt, maar sturen op verwantschap is het meest effectief.

Op basis van de analyse en de simulaties is een aantal adviezen is geformuleerd die kunnen bijdragen aan het terugdringen van de inteelttoename:

- $\quad$ De verwantschap van de dekhengsten en hengsten uit de genenbank met de huidige populatie publiceren. Dit zou aan de hand van stoplichtkleuren kunnen gebeuren om de waarde van een hengst met oog op genetische diversiteit te visualiseren. Daarnaast zal publicatie van verwantschap naar verwachting bijdragen aan de bewustwording bij fokkers;

- Het stimuleren van gebruik van dekhengsten en hengsten uit de genenbank met een lage verwantschap om meer genetische diversiteit in de populatie te brengen. Én, het gebruik van hengsten met een hoge verwantschap tot de populatie afraden;

- Het meer gelijkmatig inzetten van dekhengsten, zodat niet een beperkt aantal dekhengsten een groot deel van de fokmerries dekt;

- Inteeltberekeningen uitvoeren voor de individuele merriehouder: bij de paringskeuze wordt het inteeltpercentage van fictieve nakomelingen berekend, waarbij de merrie fictief wordt gepaard met elke beschikbare dekhengst. Een dekhengst met lagere verwantschap tot de merrie resulteert in een nakomeling met een lagere inteeltpercentage;

- $\quad$ Bij de beslissing om een hengst te selecteren de gemiddelde verwantschap tot de populatie meenemen in de afweging, dat is positief discrimineren;

- Het uitbreiden van de genenbank collectie voor het Nederlands Trekpaard, bij voorkeur met hengsten met een lage verwantschap met de populatie, om genetische diversiteit veilig te stellen;

- Het geven van voorlichting over inteelt en de mogelijke gevolgen ervan om bewustwording te vergroten;

- Meer uitwisseling van paarden met de Belgische Trekpaardenpopulatie zou kunnen bijdragen aan het terugdringen van de inteelttoename. Om de waarde hiervan te kunnen vaststellen, is vervolgonderzoek nodig waarin beide populaties worden meegenomen;

- Het vergroten van de fokpopulatie door meer mensen te interesseren voor de fokkerij en daarmee het aantal geboren veulens (die op latere leeftijd worden ingezet in de fokkerij) per jaar te verhogen. 


\subsection{Advies aanvulling genenbank collectie Nederlands Trekpaard}

Eind 2017 was sperma van 28 verschillende dekhengsten veiliggesteld in de genenbank, waarbij het aantal (inseminatie)doses sperma per hengst erg varieert. Voor het Nederlandse Trekpaardenras is nog onvoldoende materiaal opgeslagen in de genenbank om te spreken van een core collectie, een hoeveelheid hengsten én inseminatiedoses waarmee een ras weer gereconstrueerd kan worden in geval het in situ verdwenen is.

In totaal 67 dekhengsten werden geïdentificeerd die kandidaat zijn voor aanvulling van de genenbank collectie voor Nederlandse Trekpaarden. Verder was het aantal doses sperma van een aantal hengsten waarvan reeds sperma in de genenbank is veiliggesteld, soms beperkt. Aanvulling van het aantal doses sperma van deze hengsten behoorde ook tot de mogelijkheden voor uitbreiding van de collectie.

Een grote variatie in verwantschap tussen individuele dekhengsten en de (fok)merriepopulatie werd geobserveerd, waarbij dekhengsten met een lage verwantschap een interessante aanvulling van de genenbank collectie zouden kunnen vormen. Het programma GenCont selecteerde de volgende hengsten als waardevolle aanvulling van de collectie: Fonne van de Stock, Unik de Lichereau, Condor van de Bouwhoeve, Stan van Malderen van Vlaams Brabant, Amigo van Sluishoek, Falco van Waardzicht, Bart van Wienenhof (reeds materiaal in de genenbank), Bram van de Ruiting (reeds materiaal in de genenbank), Gillis van de Heirhoeve (reeds materiaal in de genenbank), Lars van de Doore Plas (reeds materiaal in de genenbank), Marius van Luchteren (reeds materiaal in de genenbank), Paul van t Clerckshof (reeds materiaal in de genenbank) en Tomba van de Kannelust (reeds materiaal in de genenbank). In 2018 zijn de eigenaren van deze hengsten benaderd met de vraag of ze sperma van hun hengst(en) willen afstaan en daarmee veiligstellen in de genenbank. 


\section{Literatuur}

FAO, Food and Agriculture Organization of the United Nations. 2013. In vivo conservation of animal genetic resources. FAO animal production and health guidelines nr. 14, Rome, ISSN 1810-0708.

García, I.P.L., B.J. Ducro, M. Maurice-van Eijndhoven and S. Janssens. 2009. Estimating genetic diversity from pedigree analysis of the Dutch and Belgian populations of draught horses. Thesis Animal Breeding and Genetics, Animal Breeding and Genomics Centre, Wageningen University.

Peerlings, J., T. van der Weerden and W. van Hoof. 2007. Het Trekpaard. ISBN 9789087400002, Roodbont | Agricultural Publishers, Zutphen.

Sargolzaei, M., H. Iwaisaki and J.J. Colleau. 2006. CFC: a tool for monitoring genetic diversity. Proceedings of the $8^{\text {th }}$ World Congress on Genetics Applied to Livestock Production, 13-18 August 2006, Belo Horizonte, Brazil, Communication 27-28 (CD-ROM).

SZH. 2018. http://szh.nl/paarden/nederlands-Trekpaard/, rasbeschrijving, geschiedenis en gebruik van het Nederlandse Trekpaard, website bezocht op 25-4-2018.

de Weerd, M. en J.K. Oldenbroek. 2010. Het paard in Nederland. CGN rapport 17, http://edepot.wur.nl/143551

Windig, J.J. en J.K. Oldenbroek. GenManSim, te downloaden via http://www.genebankdata.cgn.wur.nl/GenManSim/GenManSim.html 


\section{Bijlage 1 Genenbank collectie Nederlands Trekpaard (status 2017)}

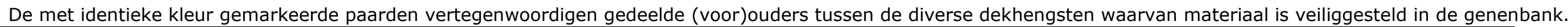

\begin{tabular}{|c|c|c|c|c|c|c|c|c|}
\hline Naam hengst & Identificatie genenbank & Geboortedatum & Aantal doses & Paardcode & Vader & Vader's vader & Moeder & Moeder's vader \\
\hline Alex van t Goed ter Kaeksmete & $2007 / 688$ & $25-07-2007$ & 3,0 & P-059299 & $\mathrm{P}-00865$ & $\mathrm{P}-\mathrm{n} n$ & P-019900 & - \\
\hline Baron van $\mathrm{t}$ Zeegat & S.257080.S & $31-03-2002$ & 16,0 & P-007591 & $\mathrm{P}-006848$ & $\overline{P-005661}$ & P-005584 & P-004806 \\
\hline Bart van Wienenhof & $528-005000-260034$ & $13-04-2005$ & 17,8 & P-011271 & & P-001369 & P-003082 & P-001306 \\
\hline Bram van de Ruiting & $2009 / 2018$ & $02-07-2007$ & 34,7 & P-018584 & $\overline{P-007591}$ & $\mathrm{P}-006848$ & P-007202 & P-000433 \\
\hline Dowan van Vrilkhoven & 528005000263459 & $21-07-2010$ & 1,4 & P-056684 & $\mathrm{P}-011271$ & & P-006983 & P-001099 \\
\hline Dylan van Hoeve Ruth & 528005000263919 & $30-05-2011$ & 2,0 & P-058771 & $\mathrm{P}-058770$ & $P-058769$ & P-007118 & P-005597 \\
\hline Eugeen van de Veldvoort & K.2916 & $30-04-1994$ & 27,8 & P-005732 & P-004823 & P-001323 & P-005733 & P-001323 \\
\hline Favoriet J van de Ruif & S.255124.K & 09-05-1998 & 2,9 & P-003369 & P-001357 & $\mathrm{P}-001754$ & P-001466 & $\mathrm{P}-001279$ \\
\hline Flor van t Cleihof & $2009 / 454$ & $28-04-2009$ & 24,4 & P-060569 & P-018032 & -005699 & P-060568 & -00865 \\
\hline Florian van t Rietenhof & $2000 / 470$ & $27-04-2000$ & 20,7 & P-009435 & P-001553 & P-001355 & P-009436 & P-001325 \\
\hline Gillis van de Heirhoeve & $2000 / 74$ & $26-04-2000$ & 4,5 & P-008443 & P-006264 & P-004297 & P-008444 & P-002097 \\
\hline Hannes van de Capreton & S.258851.S & $23-03-2003$ & 11,7 & P-008697 & P-000902 & P-001407 & P-003126 & $\mathrm{P}-001$ \\
\hline Harry van de Bomlozeput & $2004 / 804$ & $11-03-2004$ & 13,2 & P-010888 & P-007252 & P-001553 & P-007403 & P-002657 \\
\hline Igor van den Ossenberg & 528005000263386 & $24-06-2010$ & 1,6 & P-056470 & P-011091 & P-008593 & P-009942 & P-004424 \\
\hline Lars van de Doore Plas & 056006T20140456 B.S. & $02-06-2014$ & 3,1 & P-064955 & P-020477 & $\mathrm{P}-001370$ & P-008561 & P-009229 \\
\hline Lutteur van Wooldink & $528-005000-262157$ & $30-05-2008$ & 11,6 & P-019561 & P-014950 & $\mathrm{P}-008653$ & P-002477 & $\mathrm{P}-001325$ \\
\hline Marco van het Koyennehof & $2007 / 698$ & $05-06-2007$ & 4,2 & P-057279 & P-019578 & $\mathrm{P}-000172$ & P-057278 & $\mathrm{P}-008232$ \\
\hline Marius van Luchteren & 056006T20140634 B.S. & 01-03-2014 & 10,1 & P-064983 & P-020477 & P-001370 & P-064982 & \\
\hline Oscar van Wiene & S $255456 \mathrm{~K}$ & $16-05-1999$ & 56,4 & P-004920 & P-000602 & P-001463 & P-003709 & $\mathrm{P}-001754$ \\
\hline Otto van Brandevoort & K.2859 & 06-06-1989 & 51,6 & P-001434 & P-001288 & P-001302 & P-001273 & $\mathrm{P}-001279$ \\
\hline Paul van t Clerckshof & $2008 / 346$ & $20-04-2008$ & 17,2 & P-059643 & P-057565 & P-008413 & P-059194 & P-007252 \\
\hline Robert van t Clerckshof & $2007 / 446$ & 29-04-2007 & 8,1 & P-059195 & P-006952 & P-00133! & P-059194 & P-007252 \\
\hline Roel van de Lindehoef & $528-005000-260632$ & $03-04-2006$ & 15 tot 20 & P-012835 & P-001204 & P-001270 & P-008787 & P-007342 \\
\hline Texas d'Aywiers & $2008 / 154$ & $15-07-2008$ & 2,8 & P-061912 & P-005670 & P-000149 & P-061914 & onbekend \\
\hline Tomba van de Kannelust & $528-005000-262896$ & 29-05-2009 & 1,5 & P-020952 & P-012331 & & P-007194 & $\mathrm{P}-000433$ \\
\hline Twan van de Schaijksehoek & $528-005000260148$ & $10-05-2005$ & 17,2 & P-011384 & P-005762 & P-006642 & P-006051 & P-003479 \\
\hline Udo van de Zaaidijk & $528-0050002-62426$ & 02-01-2009 & 5,8 & P-020248 & $\mathrm{P}-001370$ & P-001357 & P-010823 & P-010824 \\
\hline Zephir van Waardzicht & K.2902 & 02-04-1995 & 67,8 & P-001475 & D-00175 & P-001272 & P-001476 & P-001383 \\
\hline
\end{tabular}




\section{Bijlage 2 Verwantschap tussen de huidige (fok)populatie en kandidaat dekhengsten voor aanvulling van de genenbank collectie}

Lichtblauw gemarkeerde hengsten zijn beschikbaar voor de dekdienst in 2017, hebben nog een beperkt aantal nakomelingen en zijn lager dan gemiddeld verwant aan de huidige (fok)populatie. Promotie van gebruik van deze hengsten zou kunnen bijdragen aan het inperken van de inteelttoenamen.

De hengsten zijn gesorteerd van minst (groen) tot meest (rood) verwant met de huidige (fok)populatie.

\begin{tabular}{|c|c|c|c|c|c|c|c|c|}
\hline Naam & Hengst & Vader & Moeder & Dekdienst & Inteeltpercentage & $\begin{array}{r}\text { Verwantschap met } \\
\text { (fok)populatie }\end{array}$ & $\begin{array}{r}\text { Aantal } \\
\text { nakomelingen } \\
\end{array}$ & Geboortedatum \\
\hline Codex "te Zande" & P-001304 & P-001195 & P-001305 & Voor 2017 & $0,21 \%$ & 0,048 & 53 & $25-5-1994$ \\
\hline Unik de Lichereau & P-060789 & P-060788 & P-060787 & 2017 & $0,60 \%$ & 0,050 & 1 & $20-5-2009$ \\
\hline Johan & P-001407 & P-001404 & P-001405 & Voor 2017 & $0,18 \%$ & 0,055 & 80 & $25-3-1986$ \\
\hline Charmeur van 't Spreeuwenhof & P-006852 & P-000172 & P-005267 & Voor 2017 & $2,08 \%$ & 0,062 & 54 & $14-5-2001$ \\
\hline Max des Ballons & P-060580 & P-008232 & P-060579 & Voor 2017 & $3,05 \%$ & 0,064 & 0 & $24-3-2010$ \\
\hline Jord van de Wijzend & P-058206 & P-008015 & P-011840 & Voor 2017 & $6,15 \%$ & 0,070 & 7 & $1-5-2011$ \\
\hline Nero van Berkeldal & P-006872 & P-000602 & P-000088 & Voor 2017 & $1,60 \%$ & 0,074 & 29 & $5-5-2001$ \\
\hline Jonas van Wilshof & P-002497 & P-001369 & P-002494 & Voor 2017 & $3,45 \%$ & 0,075 & 32 & 17-4-1998 \\
\hline Hepper Dilan & P-058770 & P-058769 & P-021351 & Voor 2017 & $2,39 \%$ & 0,076 & 36 & $28-7-2007$ \\
\hline Falco van de Hogerduinen & P-005731 & P-006642 & P-000651 & Voor 2017 & $0,90 \%$ & 0,078 & 51 & $23-4-2000$ \\
\hline Iwan van Wooldink & P-005762 & P-006642 & P-002477 & Voor 2017 & $0,95 \%$ & 0,079 & 92 & $5-4-2000$ \\
\hline Johan van Hoeve Ruth & P-008760 & P-001407 & P-003047 & Voor 2017 & $2,54 \%$ & 0,082 & 4 & $18-5-2003$ \\
\hline Condor van de Bouwhoeve & P-059646 & P-059195 & P-019377 & 2017 & $6,46 \%$ & 0,087 & 36 & $9-3-2012$ \\
\hline Stan van Malderen van Vlaams Brabant & P-063984 & P-011750 & P-063986 & 2017 & $2,51 \%$ & 0,090 & 0 & $23-4-2013$ \\
\hline Hepper Midas & P-057508 & P-005812 & P-057507 & 2017 & $2,89 \%$ & 0,090 & 45 & $19-6-2005$ \\
\hline Amigo van Sluishoek & P-010078 & P-003523 & P-006340 & 2017 & $3,62 \%$ & 0,090 & 26 & $13-6-2004$ \\
\hline Tim van de Wilgenhoeve & P-018598 & P-005445 & P-005139 & 2017 & $3,30 \%$ & 0,093 & 39 & $21-6-2007$ \\
\hline Jazz van de Vinkenbossen & P-063745 & P-017787 & P-020725 & 2018 & $4,19 \%$ & 0,094 & 0 & $12-6-2015$ \\
\hline Leander van de Boterhoeve & P-062933 & P-057994 & P-062935 & 2017 & $3,19 \%$ & 0,095 & 9 & $10-5-2012$ \\
\hline Zeus van Rupelmonde & P-011091 & P-008593 & P-011092 & Voor 2017 & $3,55 \%$ & 0,095 & 87 & $1-5-2003$ \\
\hline Robin van de Heuvel & P-060574 & P-057508 & P-060573 & Voor 2017 & $2,44 \%$ & 0,097 & 11 & $9-6-2009$ \\
\hline Falco van de Waardzicht & P-059912 & P-058770 & P-017897 & 2017 & $2,50 \%$ & 0,097 & 34 & $7-6-2012$ \\
\hline
\end{tabular}




\begin{tabular}{|c|c|c|c|c|c|c|c|c|}
\hline Naam & Hengst & Vader & Moeder & Dekdienst & Inteeltpercentage & $\begin{array}{l}\text { Verwantschap met } \\
\text { (fok)populatie }\end{array}$ & $\begin{array}{r}\text { Aantal } \\
\text { nakomelingen }\end{array}$ & Geboortedatum \\
\hline Landor van de Boterhoeve & $\mathrm{P}-061735$ & $\mathrm{P}-057994$ & P-061736 & 2017 & $3,56 \%$ & 0,098 & 17 & $8-5-2011$ \\
\hline Piket van den Egelenberg & P-061738 & P-018032 & P-061739 & Voor 2017 & $5,86 \%$ & 0,098 & 0 & $8-4-2011$ \\
\hline Bram van Lieshof & P-058155 & P-018584 & P-007063 & 2017 & $3,47 \%$ & 0,099 & 35 & $30-4-2011$ \\
\hline Willen van Hoeve Ruth & P-011459 & P-010708 & P-005422 & Voor 2017 & $3,21 \%$ & 0,100 & 3 & $21-5-2005$ \\
\hline Darko van de Koningshoek & P-017787 & P-010824 & P-017788 & 2017 & $3,55 \%$ & 0,100 & 29 & $11-4-2005$ \\
\hline Fonne van de Stock & P-057093 & P-005812 & P-057161 & 2017 & $4,86 \%$ & 0,100 & 14 & $29-2-2008$ \\
\hline Sam van de Vinkebossen & P-062745 & P-060574 & P-018697 & 2017 & $3,99 \%$ & 0,101 & 0 & $16-4-2014$ \\
\hline Baron van "De Witte Hoeve" & P-012413 & P-007806 & P-007844 & Voor 2017 & $3,64 \%$ & 0,102 & 24 & $24-4-2006$ \\
\hline Cassanova van de Kannelust & P-060542 & P-057508 & P-007194 & 2017 & $4,72 \%$ & 0,103 & 3 & $19-5-2012$ \\
\hline Dorus van de Molenhoeve & P-019189 & P-011091 & P-006975 & Voor 2017 & $5,25 \%$ & 0,104 & 0 & $14-4-2008$ \\
\hline Max van het Kleindal & P-062433 & P-020952 & P-010033 & 2017 & $4,90 \%$ & 0,106 & 0 & $10-6-2014$ \\
\hline Zephyr van den Hoek & P-004895 & P-001475 & P-002113 & Voor 2017 & $5,93 \%$ & 0,106 & 14 & $16-3-1999$ \\
\hline Cupido van de Joseph-Hoeve & P-011416 & P-000433 & P-000915 & Voor 2017 & $5,70 \%$ & 0,107 & 37 & $10-5-2005$ \\
\hline Hector van Waardzicht & P-062223 & P-011249 & P-056530 & 2017 & $4,06 \%$ & 0,108 & 0 & $15-4-2014$ \\
\hline Uniek van de Zaaidijk & P-063445 & P-061735 & P-020715 & 2018 & $5,47 \%$ & 0,108 & 0 & $14-5-2015$ \\
\hline Norris van de Vinkenbossen & P-062747 & P-060574 & P-061545 & 2018 & $8,28 \%$ & 0,109 & 0 & $23-5-2014$ \\
\hline Senateur van Hoeve de Eik & P-057726 & P-057723 & P-011358 & Voor 2017 & $7,01 \%$ & 0,109 & 12 & $20-4-2011$ \\
\hline Hardi van Pamel & P-010708 & P-005699 & P-010709 & Voor 2017 & $2,95 \%$ & 0,109 & 84 & $17-6-2001$ \\
\hline Star van Buitenkamp & P-004915 & P-001454 & P-002772 & Voor 2017 & $5,06 \%$ & 0,110 & 22 & $16-5-1999$ \\
\hline Tonic van Luchteren & P-019964 & P-008653 & P-019965 & Voor 2017 & $4,30 \%$ & 0,111 & 5 & $21-5-2006$ \\
\hline Gert uit de Biesbosch & P-063183 & P-061735 & P-011392 & 2018 & $4,88 \%$ & 0,113 & 0 & $25-4-2015$ \\
\hline Wisky van de Klaverhoeve & P-011511 & P-005762 & P-002341 & 2017 & $3,55 \%$ & 0,113 & 62 & $2-5-2005$ \\
\hline Pascal van de Lokkant & P-012421 & P-001443 & P-004882 & Voor 2017 & $5,68 \%$ & 0,113 & 11 & $17-4-2006$ \\
\hline Ratzinger van 't Rijkelhof & P-018096 & P-008653 & P-018097 & Voor 2017 & $3,81 \%$ & 0,114 & 7 & $20-3-2005$ \\
\hline Guido van den Houwenberg & P-001653 & P-001277 & P-001351 & Voor 2017 & $0,01 \%$ & 0,114 & 29 & $11-4-1984$ \\
\hline Amigo van Strijtem van Vlaams Brabant & P-065237 & P-065235 & P-065236 & 2018 & $7,22 \%$ & 0,115 & 3 & $18-4-2012$ \\
\hline Sjors van 't Lisje & P-019255 & P-014950 & P-002951 & Voor 2017 & $5,09 \%$ & 0,116 & 1 & $29-4-2008$ \\
\hline Tom van 't Broek & P-062140 & P-020248 & P-011546 & 2017 & $2,50 \%$ & 0,117 & 0 & $25-4-2014$ \\
\hline Karel van de Korn & P-022467 & P-012835 & P-019844 & 2017 & $5,75 \%$ & 0,117 & 9 & $10-4-2010$ \\
\hline Mette van 't Rijkelhof & P-063865 & P-020477 & P-018738 & 2017 & $7,39 \%$ & 0,118 & 8 & $15-5-2013$ \\
\hline Gilles van de Molenput & P-063956 & P-020477 & P-063955 & 2017 & $5,26 \%$ & 0,119 & 25 & $17-5-2013$ \\
\hline Fabian van Luchteren & P-061840 & P-013144 & P-058441 & Voor 2017 & $5,16 \%$ & 0,119 & 0 & $20-5-2011$ \\
\hline Arthur van Wooldink & P-020950 & P-014950 & P-002477 & 2017 & $2,94 \%$ & 0,120 & 26 & $15-6-2009$ \\
\hline Wilson van de Capreton & P-001473 & P-001754 & P-001472 & Voor 2017 & $6,78 \%$ & 0,121 & 68 & 18-4-1995 \\
\hline
\end{tabular}




\begin{tabular}{|c|c|c|c|c|c|c|c|c|}
\hline Naam & Hengst & Vader & Moeder & Dekdienst & Inteeltpercentage & $\begin{array}{r}\text { Verwantschap met } \\
\text { (fok)populatie }\end{array}$ & $\begin{array}{r}\text { Aantal } \\
\text { nakomelingen }\end{array}$ & Geboortedatum \\
\hline Pol van het Kruissewegje & P-012783 & P-001370 & P-001780 & Voor 2017 & $5,15 \%$ & 0,122 & 0 & $28-5-2006$ \\
\hline Faro van 't Hof ter Riete & P-018848 & P-008653 & P-018849 & Voor 2017 & $6,10 \%$ & 0,122 & 39 & $26-4-2004$ \\
\hline Gabor van Wooldink & P-059544 & P-011249 & P-002477 & 2017 & $7,04 \%$ & 0,124 & 2 & $19-4-2012$ \\
\hline Luuk van Wooldink & P-057899 & P-014950 & P-018274 & Voor 2017 & $4,84 \%$ & 0,124 & 0 & $4-5-2011$ \\
\hline Thor van de Kerkeveldhoeve & P-064880 & P-020477 & P-061793 & 2017 & $6,48 \%$ & 0,126 & 0 & $1-5-2014$ \\
\hline Jules van de Vendoorn & P-064970 & P-061658 & P-064969 & 2018 & $9,95 \%$ & 0,126 & 0 & $15-6-2014$ \\
\hline Tim van de Lindehoef & P-018159 & P-009435 & P-002693 & Voor 2017 & $7,15 \%$ & 0,127 & 6 & $12-5-2007$ \\
\hline Deja Vu van Waardzicht & P-063550 & P-009435 & P-008106 & 2018 & $4,63 \%$ & 0,127 & 0 & 2-7-2015 \\
\hline Bram van de Bouwhoeve & P-059648 & P-012323 & P-019163 & Voor 2017 & $5,96 \%$ & 0,127 & 0 & $15-3-2012$ \\
\hline Tinus van de Aardenhof & P-018049 & P-009435 & P-008565 & Voor 2017 & $2,27 \%$ & 0,129 & 6 & $2-5-2007$ \\
\hline Gaston van de Bouwhoeve & P-009650 & P-001370 & P-005793 & Voor 2017 & $2,48 \%$ & 0,130 & 21 & $21-4-2004$ \\
\hline Bonarius van 't Zand & P-013144 & P-005860 & P-006291 & 2017 & $8,69 \%$ & 0,131 & 57 & $21-5-2006$ \\
\hline Bienvenu van Waardzicht & P-019139 & P-009435 & P-008106 & 2017 & $4,63 \%$ & 0,132 & 71 & $14-3-2008$ \\
\hline Jannes van de Kouwehof & P-057821 & P-012835 & P-007123 & 2017 & $5,10 \%$ & 0,132 & 48 & $29-4-2011$ \\
\hline Siem van de Dekkershoef & P-059408 & P-011249 & P-019054 & 2017 & $6,51 \%$ & 0,136 & 46 & $4-4-2012$ \\
\hline Gamin van de Lindehoef & P-011249 & P-009435 & P-002693 & 2017 & $7,15 \%$ & 0,137 & 125 & $10-4-2005$ \\
\hline Louis van de Houtsberg & P-062143 & P-012835 & P-005689 & 2017 & $7,53 \%$ & 0,137 & 0 & $29-4-2014$ \\
\hline Sidonius van 't Zand & P-008147 & P-001370 & P-006060 & Voor 2017 & $8,83 \%$ & 0,144 & 67 & $3-5-2002$ \\
\hline
\end{tabular}




\section{Bijlage 3 Verwantschap tussen de huidige (fok)populatie en hengsten waarvan reeds sperma is opgeslagen in de genenbank}

De hengsten staan gesorteerd van minst (groen) tot meest (rood) verwant met de (fok)populatie.

\begin{tabular}{|c|c|c|c|c|c|c|c|c|}
\hline Naam & Hengst & Vader & Moeder & Dekdienst & Inteeltpercentage & $\begin{array}{l}\text { Verwantschap met } \\
\text { (fok)merriepopulatie }\end{array}$ & $\begin{array}{r}\text { Aantal } \\
\text { nakomelingen }\end{array}$ & Geboortedatum \\
\hline Eugeen van de Veldvoort & P-005732 & P-004823 & P-005733 & Voor 2017 & $13,64 \%$ & 0,029 & 53 & $30-04-1994$ \\
\hline Texas d'Aywiers & P-061912 & P-005670 & P-061914 & Voor 2017 & $0 \%$ & 0,048 & 0 & $15-07-2008$ \\
\hline Harry van de Bomlozeput & P-010888 & P-007252 & P-007403 & Voor 2017 & $2,06 \%$ & 0,051 & 49 & $11-03-2004$ \\
\hline Twan van de Schaijksehoek & P-011384 & P-005762 & P-006051 & Voor 2017 & $0,66 \%$ & 0,058 & 42 & $10-05-2005$ \\
\hline Baron van $t$ Zeegat & P-007591 & P-006848 & P-005584 & Voor 2017 & $0,80 \%$ & 0,061 & 304 & $31-03-2002$ \\
\hline Marco van het Koyennehof & P-057279 & P-019578 & P-057278 & Voor 2017 & $3,04 \%$ & 0,066 & 35 & $05-06-2007$ \\
\hline Hannes van de Capreton & P-008697 & P-000902 & P-003126 & 2017 & $2,78 \%$ & 0,067 & 111 & $23-03-2003$ \\
\hline Gillis van de Heirhoeve & P-008443 & P-006264 & P-008444 & 2017 & $2,91 \%$ & 0,068 & 84 & $26-04-2000$ \\
\hline Paul van t Clerckshof & P-059643 & P-057565 & P-059194 & 2017 & $1,23 \%$ & 0,081 & 50 & $20-04-2008$ \\
\hline Dylan van Hoeve Ruth & P-058771 & P-058770 & P-007118 & Voor 2017 & $2,42 \%$ & 0,083 & 2 & $30-05-2011$ \\
\hline Bart van Wienenhof & P-011271 & P-005445 & P-003082 & 2017 & $2,34 \%$ & 0,085 & 211 & $13-04-2005$ \\
\hline Igor van den Ossenberg & P-056470 & P-011091 & P-009942 & Voor 2017 & $4,15 \%$ & 0,087 & 19 & $24-06-2010$ \\
\hline Robert van t Clerckshof & P-059195 & P-006952 & P-059194 & 2017 & $1,93 \%$ & 0,092 & 111 & 29-04-2007 \\
\hline Bram van de Ruiting & P-018584 & P-007591 & P-007202 & Onbekend & $1,71 \%$ & 0,096 & 47 & $02-07-2007$ \\
\hline Oscar van Wiene & P-004920 & P-000602 & P-003709 & Voor 2017 & $1,25 \%$ & 0,097 & 120 & $16-05-1999$ \\
\hline Dowan van Vrilkhoven & P-056684 & P-011271 & P-006983 & Voor 2017 & $2,97 \%$ & 0,103 & 44 & $21-07-2010$ \\
\hline Otto van Brandevoort & P-001434 & P-001288 & P-001273 & Voor 2017 & $0,04 \%$ & 0,103 & 181 & 06-06-1989 \\
\hline Lars van de Doore Plas & P-064955 & P-020477 & P-008561 & 2017 & $3,70 \%$ & 0,106 & 0 & $02-06-2014$ \\
\hline Florian van t Rietenhof & P-009435 & P-001553 & P-009436 & 2017 & $3,64 \%$ & 0,111 & 209 & $27-04-2000$ \\
\hline Flor van t Cleihof & P-060569 & P-018032 & P-060568 & 2017 & $10,95 \%$ & 0,115 & 11 & 28-04-2009 \\
\hline Zephir van Waardzicht & P-001475 & P-001754 & P-001476 & Onbekend & $4,11 \%$ & 0,118 & 86 & 02-04-1995 \\
\hline Marius van Luchteren & P-064983 & P-020477 & P-064982 & 2017 & $4,48 \%$ & 0,122 & 0 & $01-03-2014$ \\
\hline Lutteur van Wooldink & P-019561 & P-014950 & P-002477 & 2017 & $2,94 \%$ & 0,122 & 71 & $30-05-2008$ \\
\hline Tomba van de Kannelust & P-020952 & P-012331 & P-007194 & 2017 & $7,41 \%$ & 0,126 & 39 & $29-05-2009$ \\
\hline
\end{tabular}




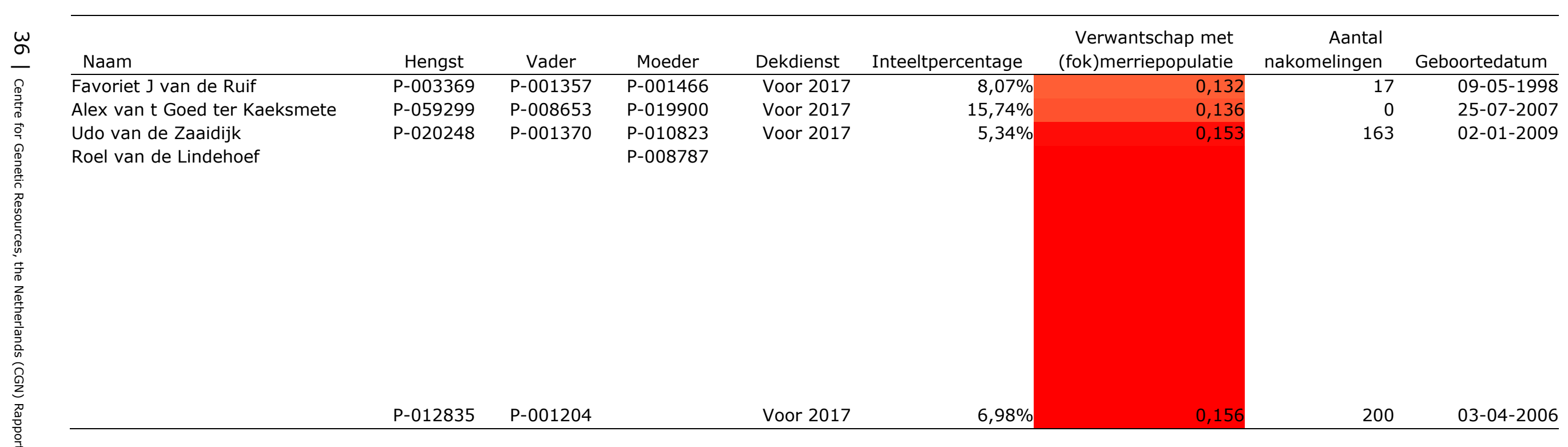




\section{Bijlage 4 Verwantschap tussen hengsten waarvan eind 2017 reeds sperma is veiliggesteld in de genenbank}

De tabel geeft een gedetailleerd overzicht van de gekwantificeerde onderlinge relaties tussen de dekhengsten waarvan materiaal is veiliggesteld in de genenbank (status eind 2017). Een tweetal vadernakomeling relaties zijn aanwezig (verwantschap $~ 0,5$ : Bart van Wienenhof is de vader van Dowan van

Vrilkhoven en Baron van $t$ Zeegat is de vader van Bram van de Ruiting), evenals half-sibs (verwantschap $\sim 0,25$ : bijv. Lars van de Doore Plas en Marius van Luchteren). Aangezien een core collectie uitgaat van 50 onverwante mannelijke dieren, is met het huidige aantal met inachtneming van de relaties tussen de hengsten de core collectie voor het Nederlands Trekpaard nog niet bereikt.

De gemiddelde verwantschap kan variëren van 0 tot 1 , waarbij 0 aangeeft dat dekhengsten ongerelateerd zijn (richting donkergroen) en 1 dat dekhengsten volledig gerelateerd zijn (richting rood).

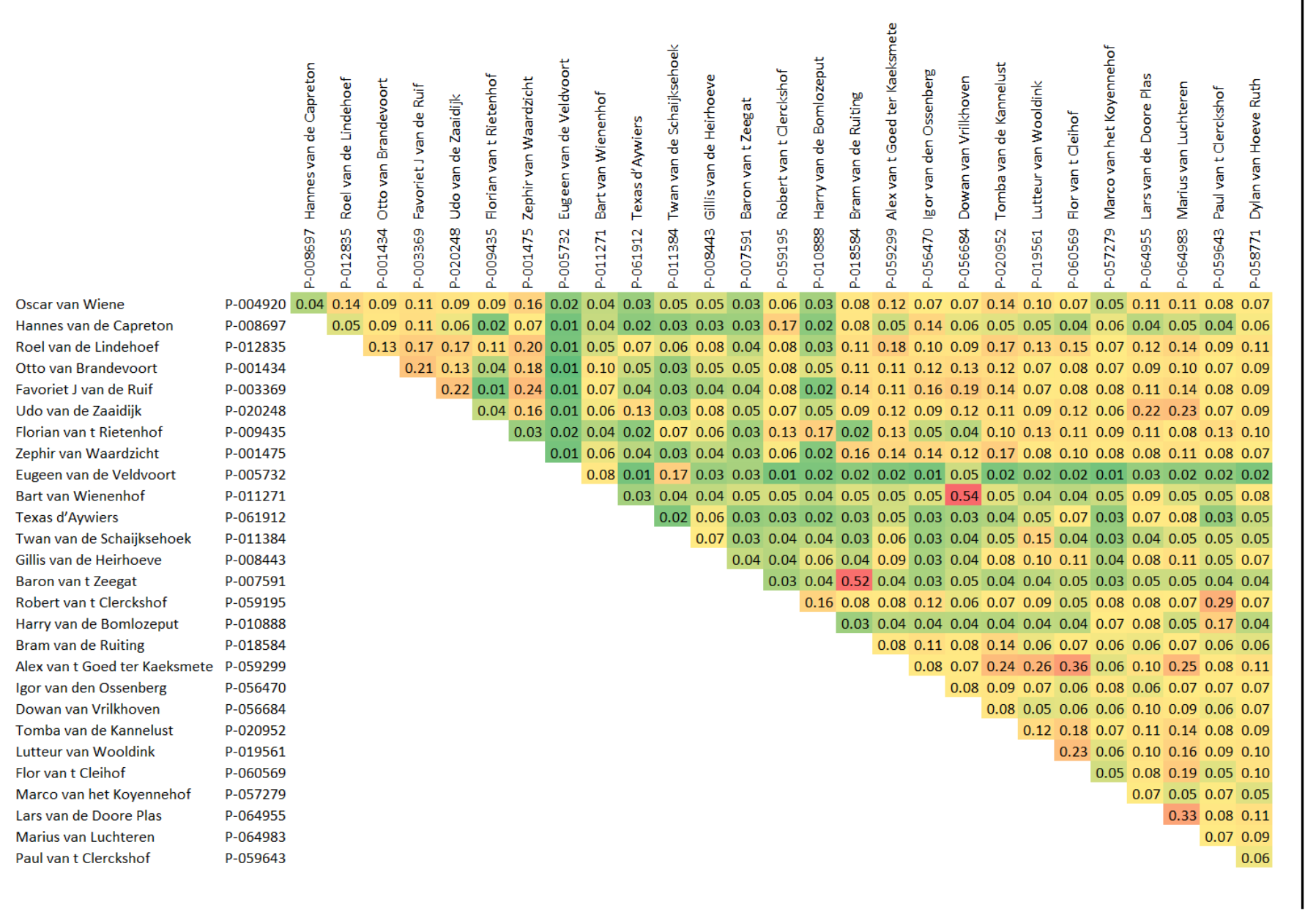



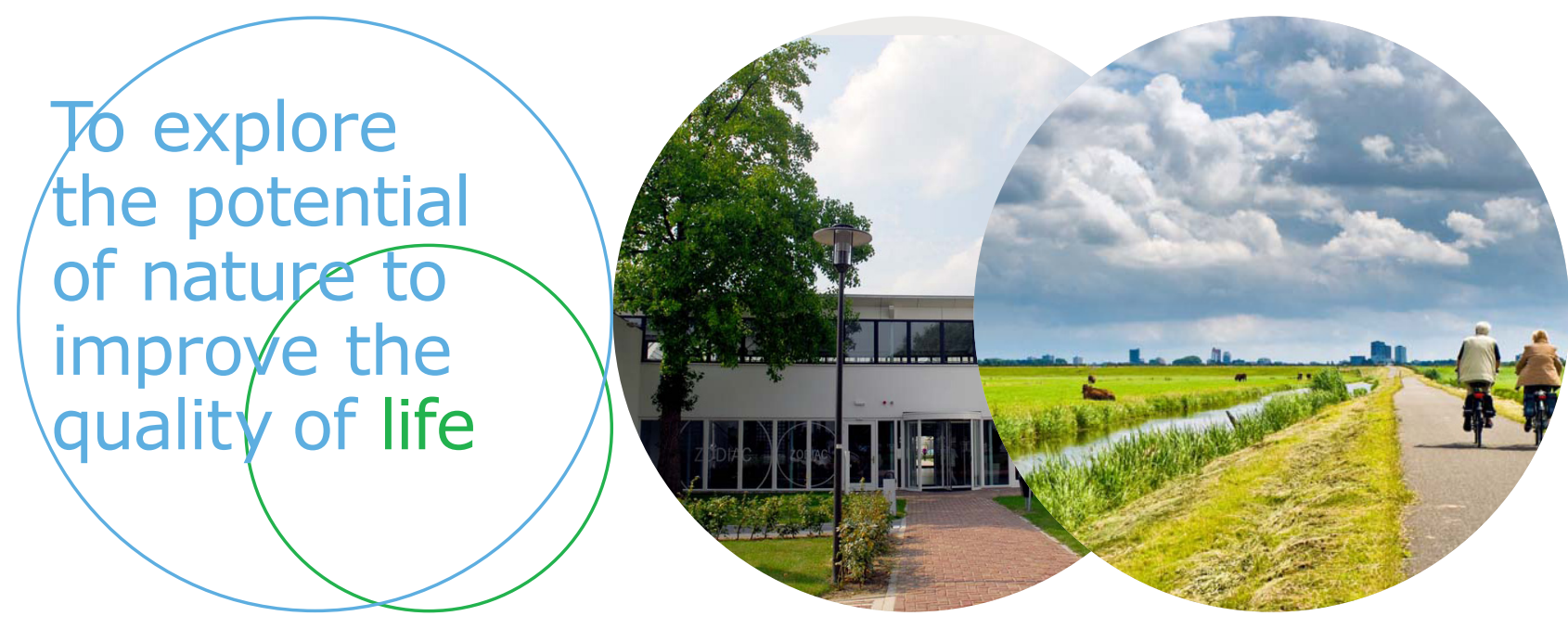

CGN

Postbus 338

$6700 \mathrm{AH}$ Wageningen

cgn@wur.nl

www.wur.nl/cgn

Wageningen University \& Research CGN rapport 41
De missie van Wageningen University \& Research is 'To explore the potential of nature to improve the quality of life'. Binnen Wageningen University \& Research bundelen 9 gespecialiseerde onderzoeksinstituten van Stichting Wageningen Research en Wageningen University hun krachten om bij te dragen aan de oplossing van belangrijke vragen in het domein van gezonde voeding en leefomgeving. Met ongeveer 30 vestigingen, 6.500 medewerkers en 10.000 studenten behoort Wageningen University \& Research wereldwijd tot de aansprekende kennisinstellingen binnen haar domein. De integrale benadering van de vraagstukken en de samenwerking tussen verschillende disciplines vormen het hart van de unieke Wageningen aanpak. 